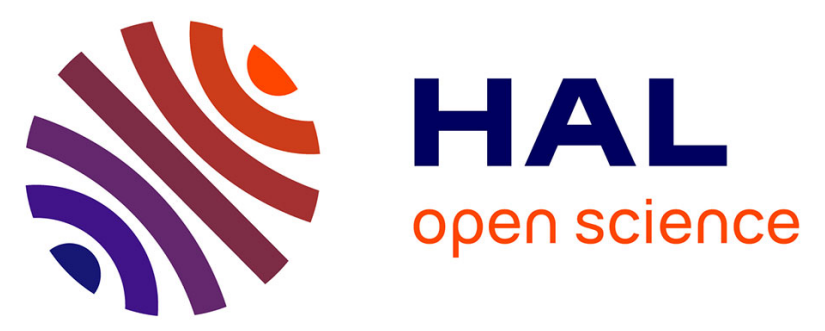

\title{
Annonacin, a natural lipophilic mitochondrial complex I inhibitor, increases phosphorylation of tau in the brain of FTDP-17 transgenic mice.
}

Elizabeth S. Yamada, Gesine Respondek, Stefanie Müssner, Anderson de Andrade, Matthias Höllerhage, Christel Depienne, Agnès Rastetter, Agathe Tarze, Bertrand Friguet, Mohamed Salama, et al.

\section{To cite this version:}

Elizabeth S. Yamada, Gesine Respondek, Stefanie Müssner, Anderson de Andrade, Matthias Höllerhage, et al.. Annonacin, a natural lipophilic mitochondrial complex I inhibitor, increases phosphorylation of tau in the brain of FTDP-17 transgenic mice.. Experimental Neurology, 2014, 253, pp.113-25. 10.1016/j.expneurol.2013.12.017 . inserm-00974704

\section{HAL Id: inserm-00974704 https://www.hal.inserm.fr/inserm-00974704}

Submitted on 7 Apr 2014

HAL is a multi-disciplinary open access archive for the deposit and dissemination of scientific research documents, whether they are published or not. The documents may come from teaching and research institutions in France or abroad, or from public or private research centers.
L'archive ouverte pluridisciplinaire HAL, est destinée au dépôt et à la diffusion de documents scientifiques de niveau recherche, publiés ou non, émanant des établissements d'enseignement et de recherche français ou étrangers, des laboratoires publics ou privés. 


\section{Annonacin, a natural lipophilic mitochondrial complex I inhibitor, increases phophorylation of tau in the brain of FTDP-17 transgenic mice}

Elizabeth S. Yamada ${ }^{1,2, *}$, Gesine Respondek ${ }^{1,3,4, *}$, Stefanie Müssner ${ }^{1, *}$, Anderson C. F. de Andrade $^{1,3,4}$, Mathias Höllerhage ${ }^{1,3,4}$, Christel Depienne ${ }^{5}$, Agnès Rastetter ${ }^{5}$, Agathe Tarze ${ }^{6}$, Bertrand Friguet ${ }^{7}$, Mohamed Salama ${ }^{1}$, Pierre Champy ${ }^{8}$, Wolfgang H. Oertel ${ }^{1}$, Günter U. Höglinger ${ }^{1,3,4}$

${ }^{1}$ Experimental Neurology, Philipps University, D-35037 Marburg, Germany

${ }^{2}$ Experimental Neuropathology Laboratory, University Hospital João de Barros Barreto, Federal University of Pará, 66073-000 Belém, Brasil

${ }^{3}$ German Center for Neurodegenerative Diseases (DZNE), D-81677 Munich, Germany

${ }^{4}$ Department of Neurology, Technical University Munich, D-81377 Munich, Germany

${ }^{5}$ INSERM, Unité 679, Experimental Neurology and Therapeutics, Hôpital de la Salpêtrière, 75013 Paris, France

${ }^{6}$ Université Paris-Est, UMR_S955, UPEC, F-94000 Créteil, France

${ }^{7}$ Laboratoire de Biologie Cellulaire du Vieillissement, UR4-IFR83, Université Pierre et Marie Curie-Paris 6, 4 place Jussieu, 75252 Paris Cedex 05, France

${ }^{8}$ Laboratoire de Pharmacognosie, CNRS UMR 8076 BioCIS, Labex LERMIT, Faculté de Pharmacie, Université Paris-Sud, 92296 Châtenay-Malabry, France

${ }^{*}$ These authors contributed equally

Correspondence should be addressed to Günter U. Höglinger, Dept. of Translational Neurodegeneration, German Center for Neurodegenerative Diseases (DZNE), München, Max 
Lebsche Platz 30, D-81677 Munich, Germany. Phone: +49-89-7095-8406, Fax: +49-89-218075432-8406, E-mail: guenter.hoeglinger@dzne.de

\begin{abstract}
Both genetic and environmental factors likely contribute to the neuropathology of tauopathies, but it remains unclear how specific genetic backgrounds affect the susceptibility towards environmental toxins. Mutations in the tau gene have been associated with familial tauopathies, while annonacin, a plant-derived mitochondrial inhibitor, has been implicated in an environmental form of tauopathy. We therefore determined whether there was a pathogenic synergy between annonacin exposure and the expression of the R406W-tau mutation in transgenic mice. We found that annonacin exposure caused an increase in the number of neurons with phosphorylated tau in the somatodendritic compartment in several brain areas in $\mathrm{R} 406 \mathrm{~W}^{+/+}$mice as opposed to mice that had only the endogenous mouse tau $\left(\mathrm{R} 406 \mathrm{~W}^{-/-}\right)$. Western blot analysis demonstrated a concomitant increase in total tau protein without increase in tau mRNA, but reduced proteasomal proteolytic activity in $\mathrm{R} 406 \mathrm{~W}^{+/+}$, but not $\mathrm{R} 406 \mathrm{~W}^{-/-}$ mice, upon annonacin-treatment. Phosphorylated tau levels exceeded the increase in total tau protein, along with increased levels of different tau kinases, foremost a striking increase in the p25/p35 ratio, known to activate the tau kinase Cdk5. In summary, we observed a synergistic interaction between annonacin exposure and the presence of the R406W-tau mutation, which resulted in reduced degradation, increased phosphorylation and redistribution of neuronal tau.
\end{abstract}

Keywords: environmental neurotoxin, microtubule-associated protein tau, neurodegeneration, tauopathy

\title{
Abbreviations
}


Cdk5: cyclin-dependent kinase 5; FTDP-17: frontal temporal dementias with parkinsonism linked to chromosome 17; GSK-3 $\beta$ : glycogen synthase kinase $3 \beta$; MAPK (Erk1/2): mitogenactivated protein kinase; SAPK: stress-activated protein kinase 


\section{Introduction}

The microtubule-associated protein tau (MAPT), normally found in axons, is involved in microtubule polymerization and stabilization (Weingarten et al., 1975). From one MAPT gene on chromosome 17q21 encoding 16 exons, six different tau protein isoforms are generated by alternative splicing in the adult human brain (Lee et al., 2001). Tauopathies are neurodegenerative diseases defined by the presence of filamentous inclusions of hyperphosphorylated tau in neurons or glial cells (Ballatore et al., 2007). Present evidence strongly suggests that the etiological spectrum of tauopathies ranges from monogenetic variants to predominantly environmental forms, with a rather large group of "sporadic" forms occupying the middle spectrum, where a genetic predisposition and hypothetical environmental triggers are probably jointly involved.

An example of an environmentally caused tauopathy is the atypical Parkinson syndrome endemic in Guadeloupe, linked to high consumption of nutritional products of Annonaceae plants (Caparros-Lefèbvre et al., 1999; Champy et al., 2005, 2009; Lannuzel et al., 2007). The implicated neurotoxins are Annonaceous acetogenins, a unique family of potent and lipophilic inhibitors of complex I of the respiratory chain (Bermejo et al., 2005) showing tropism towards mitochondria (Derbré et al., 2005; Kojima et al., 2010). Annonacin, a prototypical representative of this class, causes neuronal loss and somatodendritic accumulation of phospho-tau in vivo and in vitro (Lannuzel et al., 2003; Champy et al., 2004; Escobar-Khondiker et al., 2007). A systematic investigation of 24 globally distributed lipophilic complex I inhibitors has demonstrated a correlation between their potency to inhibit mitochondrial complex I with their potency to induce somatodendritic redistribution of phosphorylated tau protein in cultured rodent striatal neurons (Höllerhage et al., 2009). Finally, a number of studies in patients with progressive supranuclear palsy, a prototypical tauopathy, using different methodological approaches, point to a primary impairment of mitochondrial energy metabolism (Martinelli et al., 2000; Swerdlow et al., 2000; Albers et al., 2001; 
Stamelou et al., 2009). Together, these clinical and experimental observations suggest that that complex I inhibition could contribute to pathogenic mechanisms in some sporadic tauopathies.

At the other end of the spectrum, 44 pathogenic MAPT mutations have been associated with a wide range of autosomal dominantly inherited tauopathies, as the frontotemporal dementias with parkinsonism linked to chromosome 17 (FTDP-17-Tau; Foster et al., 1997; Lee et al., 2001). Typically, the neuropathological findings consist of frontotemporal neuronal loss and gliosis with intraneuronal neurofibrillary tangles (NFTs) and, occasionally, glial tau deposits (van Swieten et al, 1999; Lindquist et al., 2008). Interestingly, distinct clinical presentations may occur in association with the same mutation (Lee et al., 2001; Reed et al., 2001; Baba et al., 2005), even within the same family (Bird et al., 1999), suggesting that additional genetic or environmental modifiers contribute to the determination of the final clinical and neuropathological phenotype.

The R406W mutation is a particularly interesting MAPT missense mutation in exon 13 (Arg ${ }^{406}$ to Trp, numbered according to the longest tau isoform), first described in North America (Reed et al., 1997; Hutton et al., 1998), later in the Netherlands (Rizzu et al., 1999; van Swieten et al. 1999), Belgium (Rademaker et al., 2003), Sweden (Ostojic et al, 2004; Passant et al., 2004), Denmark (Lindquist et al., 2008, 2009) and Japan (Ikeuchi et al., 2008). High variability in the clinical manifestation has been described between and within R406W kindreds. Age of onset varied from 45 to 75 years and most studied cases initially resemble Alzheimer disease (AD) with early memory impairment, with frontal lobe symptoms and language problems appearing later (Reed et al., 1997; Lindquist et al., 2008). However, some patients showed frontal personality changes as the earliest and most striking feature with the presence of parkinsonian symptoms being variable (Reed et al., 1997; van Swieten et al., 1999).

The phenotypic variability of inherited tauopathies suggests the presence of environmental modifiers. Potential candidates are toxins already implicated in environmental 
variants of tauopathies. Searching for gene-environment interactions leading to pathogenic synergy, we investigated therefore the effects of annonacin in mice overexpressing the longest human tau isoform with the R406W mutation (Zhang et al., 2004).

\section{Methods}

\section{Animals}

$\mathrm{R}_{406 \mathrm{~W}^{+/+}}$transgenic mice breeder pairs were donated by Dr. Virginia M.-Y. Lee, University of Pennsylvania School of Medicine (Philadelphia, USA). Their full description is given at Zhang et al. (2004). Briefly, the longest human tau isoform containing the R406W mutation was cloned into the mouse prion promoter (MoPrP.Xho) expression vector at the XhoI site, and fertilized in a mixed C57BL6 x C3H (B6C3/F1) strain background. Homozygous $\mathrm{R} 406 \mathrm{~W}^{+/+}$and non-transgenic wild-type $\left(\mathrm{R} 406 \mathrm{~W}^{-/}\right)$mice used were kept in the same B6C3 background. Only males were used in the experiments. The genotype was confirmed by genomic DNA samples isolated from the tails using a peqGold tissue DNA extraction kit (PEQLAB, Erlangen, Germany). Cerebral expression of the mutated human protein was confirmed by Western blots.

\section{Complex I inhibitor}

Annonacin was obtained from fruit pulp of Annona muricata, as described (Champy et al., 2005). The purity of this compound was confirmed by analytical reversed-phase HPLCDAD/ESI-Q-MS.

\section{Annonacin exposure}

The animal work was approved by the appropriate governmental authority (Regierungspräsidium Giessen, V54-19c20/15(1)MR20/15-Nr03/2005) and conducted in accordance to the European Community Council Directive 86/609/EEC. Male R406W ${ }^{-/-}$and 
$\mathrm{R}_{406 \mathrm{~W}^{+/+}}$mice were $16-18$ weeks old, weighting $30-40 \mathrm{~g}$ at the time of operation. Three to six animals were housed per cage with free access to food and water under a $12-\mathrm{h} / 12-\mathrm{h}$ light/dark cycle at $26^{\circ} \mathrm{C}$. Osmotic mini-pumps (Alzet 1003, $100 \mu 1,1.04 \mu \mathrm{l} / \mathrm{h}$; Charles River Laboratory, Sulzfeld, Germany) were filled with solutions containing annonacin or vehicle in equal volumes of dimethylsulfoxide (DMSO) and polyethyleneglycol 400 (PEG) and incubated in sterile $0.9 \%$ (wt/vol) $\mathrm{NaCl}$ for $4 \mathrm{~h}$ prior to implantation. Mice were anaesthetized by an intraperitoneal (i.p.) injection of $10 \mathrm{~mL} / \mathrm{kg}$ of ketamine:xylazine:saline (1:1:8), corresponding to a dose of $10 \mathrm{mg} / \mathrm{kg}$ of ketamine and $20 \mathrm{mg} / \mathrm{kg}$ of xylazine. Pumps were implanted under the skin on the back of the mice, at approximately the level of the cervical column. Forty-one $\mathrm{R}_{406 \mathrm{~W}^{-/-}}$and $42 \mathrm{R} 406 \mathrm{~W}^{+/+}$mice were infused with annonacin at a rate of 0,6 or $9 \mathrm{mg} / \mathrm{kg} / \mathrm{day}$, calculated with respect to their body weight. A higher dose of $12 \mathrm{mg} / \mathrm{kg} /$ day provoked $100 \%$ mortality within 3 days of exposure and was not further pursued. Animals were weighted before and after the 3-day infusion period.

\section{Tissue preparation}

After the 3-day infusion period, mice received a lethal dose of $200 \mathrm{mg} / \mathrm{kg}$ of sodium pentobarbital i.p. and were perfused transcardially with ice-cold $0.1 \mathrm{M}$ phosphate-buffered saline (PBS) for 2 minutes. Thereafter, the brains were quickly removed. The hemispheres were separated by a mid-sagittal cut. One hemisphere was post-fixed in $4 \%$ (wt/vol) paraformaldehyde in $0.1 \mathrm{M}$ PBS for $24 \mathrm{~h}$, cryoprotected in $10 \%$ (wt/vol) sucrose in $0.1 \mathrm{M}$ PBS for $48 \mathrm{~h}$, frozen in isopentane at $-30^{\circ} \mathrm{C}$ for $2 \mathrm{~min}$ and stored at $-80^{\circ} \mathrm{C}$ for histology. The other hemisphere was immediately dissected, frozen in $-30^{\circ} \mathrm{C}$ isopentane and stored at $-80^{\circ} \mathrm{C}$ for western blotting, measurement of proteasomal proteolytic activities and quantitative PCR. A minimum of three samples per treatment group was analyzed in each assay.

\section{Immunohistochemistry}


Brains were cut into $40-\mu \mathrm{m}$ sections using a cryostat (Leica, Wetzlar, Germany), collected in 10 regularly spaced series, and stored in $0.1 \mathrm{M}$ PBS containing $0.01 \%$ (wt/vol) sodium azide at $4^{\circ} \mathrm{C}$. Free-floating sections were incubated successively for 15 min with $0.1 \%$ $\mathrm{H}_{2} \mathrm{O}_{2}$ in $0.1 \mathrm{~mol} / \mathrm{L}$ PBS to block endogenous peroxidase activity, for $1 \mathrm{~h}$ with $5 \%$ (vol/vol) normal donkey serum (NDS) in $0.1 \mathrm{M} \mathrm{PBS}$ and $0.2 \%$ Triton X-100 to inhibit non-specific binding sites, and for $24 \mathrm{~h}$ at $4^{\circ} \mathrm{C}$ with the mouse monoclonal primary antibodies raised against the following phospho-tau epitopes: AT270 antibody against pT181, AT8 antibody against pS202/pT205, AT100 antibody against pT212/pS214, AT180 antibody against pT231, (all from Thermo Scientific, Rockford, IL, USA; used 1:100), and AD2 antibody against pS396/pS404 (Bio-Rad, Hercules, CA; 1:1000). We used the anti-NeuN mouse monoclonal antibody (Millipore, Billerica, MA, USA; 1:1000) for labeling neurons, and the anti-Iba1 rabbit polyclonal antibody (Wako, Osaka, Japan; 1:1000) for microglia. All antibodies were diluted in $0.1 \mathrm{M}$ PBS with 5\% NDS and 0.2\% Triton X-100. Sections were then incubated for $2 \mathrm{~h}$ at room temperature with the appropriate biotinylated secondary antibody (anti-rabbit or antimouse IgG; Jackson ImmunoResearch, West Grove, PA, USA; 1/200) in 0.1 M PBS. The signal was amplified with the avidin-biotin method (VECTASTAIN Elite ABC Kit, Vector Laboratories, Burlingame, CA, USA; 1:200). Bound antibodies were visualized with $0.5 \mathrm{mg} / \mathrm{ml}$ of 3,3'-diamino-benzidine-tetrachloride (DAB, Sigma-Aldrich, Munich, Germany). To exclude non-specific labeling, the primary antibodies were omitted.

\section{Image analysis}

Phospho-tau labeled neurons were analyzed in 5-7 animals per group for $\mathrm{R} 406 \mathrm{~W}^{-/-}$and 10-12 per group for R406 $\mathrm{W}^{+/+}$. Neu-N labeled neurons and Iba1 labeled microglia were analysed in 3-5 animals per group.

Stereological cell counts were done by an observer blinded to the animals' identity on regularly spaced (1/10) sections (average post-processing thickness $20 \mu \mathrm{m}$ ) under a 40x 
objective on an Olympus Microphot with the optical fractionator method using the StereoInvestigator software (MicroBrightField, Inc., Williston, VT, USA) in the frontal and parietal cortex of one hemisphere. Frontal cortex was analysed between 1.94 and $0.86 \mathrm{~mm}$ anterior and 0 to $2.0 \mathrm{~mm}$ lateral from bregma; parietal cortex between 1.1 and $2.3 \mathrm{~mm}$ posterior and 1.0 to $3.0 \mathrm{~mm}$ lateral from bregma. Coordinates were based on Paxinos and Franklin (2004). Our criterion for counting a neuron was the presence of its nucleus either within the counting frame, or touching its right or top limit, but not touching its left or bottom limit. Total cell numbers were estimated by integration along the rostrocaudal extent of the structures. This sampling strategy gave a Schäfer coefficient of error $\leq 0.12$.

Because of the small volume of the amygdala, neurons therein were counted in one anatomically matched section per animal, sampling through the basolateral nucleus at approximately $1.34 \mathrm{~mm}$ posterior from bregma. The estimate was then normalized to the area of the structure.

Phospho-tau immunoreactivity in the hippocampus was determined on three regularly spaced, anatomically matched sections (from $-1.5 \mathrm{~mm}$ to -2.3 in relation to bregma; Paxinos and Franklin, 2004) by taking pictures with an Olympus-E330 camera with a Componon-S 2.8/50 magnification lens, attached to a light table (Copylizer eVision exe.cutive, Kaiser Fototechnik, Buchen, Germany). Pictures were analysed using Image-J software (U.S. National Institutes of Health, MD, USA, http://imagej.nih.gov/ij) to measure the mean grayness of C2/C3 region, from which the background grayness of the molecular layer was subtracted.

\section{Western blots}

Proteins were extracted in commercial tissue lysing buffer (T-PER Tissue Protein Extraction Reagent, Thermo Scientific, Rockford, USA) containing inhibitors of proteases and phosphatases (Halt Protease Inhibitor Cocktail, Halt Phosphatase Inhibitor Cocktail, 1\% each, 
Thermo Scientific). After centrifugation $\left(10,000 \times \mathrm{g}, 4^{\circ} \mathrm{C}, 5 \mathrm{~min}\right)$, supernatants were recovered and separated by $10 \%$ sodium dodecyl sulfate polyacrylamide gel electrophoresis.

To prepare sarkosyl-insoluble protein extracts, the remaining pellets were further processed according to Delobel et al. (2008) with minor modifications. After homogenization of the pellets in the lysing buffer containing protease- and phosphatase-inhibitors and centrifugation at $4000 \times \mathrm{g}, 4^{\circ} \mathrm{C}$, for $20 \mathrm{~min}, 1 \%$ sarkosyl was added to the supernatants and incubated for 1.5 hours at room temperature, then spun at $80,000 \mathrm{x} g$ for $30 \mathrm{~min}$. The pellets were then resuspended in $10 \mu \mathrm{l}$ of $50 \mathrm{mmol} / \mathrm{L}$ Tris/HCL, pH 7.4 and also separated by $10 \%$ sodium dodecyl sulfate polyacrylamide gel electrophoresis.

Proteins were then transferred onto nitrocellulose membranes and incubated with the following primary antibodies: anti-Tau5, 1:10000, anti- $\alpha$-Synuclein, 1:1000 (Chemicon, Billerica, USA); anti-Tau14, 1:1000 (Zymed Laboratories, San Francisco, USA); anti-HT7, 1:1000, anti-AT8, 1:1000, anti-AT180, 1:1000 (Thermo Scientific, Waltham, USA); antiphospho-SAPK/JNK [Thr ${ }^{183} /$ Tyr $^{185}$ ], 1:1000, anti-p44/42-MAPK [Erk1/2], 1:1000, phosphoGSK-3 $\beta$ [Ser9], 1:1000 (Cell Signaling, Danvers, USA); anti-phospho-GSK-3 $\beta$ [pY216], 1:500 (BD Transduction Laboratories, Franklin Lakes, USA); anti-GSK-3 $\beta, 1: 1000$, anti-p35, 1:1000, anti-p25, 1:1000, anti-Cdk5, 1:50000, anti-ß-actin, 1:1000 (Santa Cruz, Santa Cruz, USA). Immunoreactivity was revealed with the chemiluminescent substrate kit (Pierce ECL Western Blotting Substrate, Thermo Scientific) and exposed on x-ray films (Amersham Hyperfilm TM ECL, GE Healthcare).

\section{Proteasomal peptidase activities}

Brain samples collected from frontal cortex of $\mathrm{R} 406 \mathrm{~W}^{-/-}$and $\mathrm{R} 406 \mathrm{~W}^{+/+}$mice treated with $9 \mathrm{mg} / \mathrm{kg} / \mathrm{d}$ or vehicle were analyzed. Supernatants were collected after sonication and centrifugation $\left(20,000 \times \mathrm{g}, 4^{\circ} \mathrm{C}, 20 \mathrm{~min}\right)$. Degradation of $25 \mu \mathrm{M}$ Suc-Leu-Leu-Val-Tyr-7amido-4-methylcoumarin (chymotrypsin (CT)-like activity), $40 \mu \mathrm{M}$ N-t-Boc-Leu-Ser-Thr-Arg- 
7-amino-4-methylcoumarin (trypsin (T)-like activity), and $150 \mu \mathrm{M}$ N-Cbz-Leu-Leu-Glu-betanaphthylamide (peptidylglutamyl-peptide hydrolase (PGPH) activity) (substrates from SigmaAldrich) was monitored for $20 \mathrm{~min}$ using $20 \mu \mathrm{g}$ protein in $200 \mu \mathrm{l}$ Tris- $\mathrm{HCl}$ at $37^{\circ} \mathrm{C}$ by spectrofluorimetry (excitation/emission wavelengths: 350/440 nm for 7-amino-4methylcoumarin, 333/410 nm for beta-naphtylamine). Peptidase activities were calculated from the slopes of the linear curves in relation to standards generated using pure fluorescent products.

\section{Quantitative PCR}

Total RNA from mouse brain was isolated (Qiagen RNeasy Mini kit, Invitrogen, Grand Island, NY, USA) and RNA integrity was controlled with a 2100 Bioanalyzer (Agilent Technologies, Santa Clara, CA, USA). First-strand synthesis was performed with $100 \mathrm{ng}$ of total RNA (SuperScript III First-Strand Kit, Invitrogen). Real-time PCR experiments were performed using $5 \mu \mathrm{l}$ of 1/20 diluted RT-PCR products, $0.4 \mu \mathrm{M}$ of each primer and $12.5 \mu \mathrm{l}$ of Sybr Green PCR master mix (Applied Biosystems, Foster City, CA, USA) in a total volume of $25 \mu 1$. Two primer pairs, one specific for human MAPT (forward:

GCTCCAAAGACACCACCCA; reverse: GCTGTAGCCGCTGCGATC) and one amplifying both human and mouse MAPT cDNA (forward: GGCTCCACTGAGAACCTGAA; reverse: CCGGGACGTGTTTGATATT) were designed using primer Express 1.0. $\beta$-actin (forward: CTGTGTGGATCGGTGGCTC, reverse: CTGCTTGCTGATCCACATCTG) was used as control gene. Each sample was run in triplicate on an ABI PRISM 7500 Detection system (Applied Biosystems) and three different experiments were used for final quantifications.

\section{Statistical analysis}

For statistical analysis we used GraphPad Prism 5.0 (La Jolla, CA, USA). Results were expressed as mean \pm SEM. A p-value $<0.05$ was assumed to be statistically significant. The 
experimental groups were compared with a one-way analysis of variance (ANOVA) with the Newman-Keuls post-hoc test, or two-way ANOVA followed by a post-hoc least significant difference (LSD) test, as appropriate.

\section{Results}

\section{Annonacin-induced mortality}

Vehicle-treated animals showed no mortality. Both $\mathrm{R} 406 \mathrm{~W}^{-/-}$or $\mathrm{R} 406 \mathrm{~W}^{+/+}$mice, treated with doses of 6 and $9 \mathrm{mg} / \mathrm{kg} / \mathrm{day}$ of annonacin for 3 days, had a mortality rate of $6-13 \%$.

\section{Annonacin increases phospho-tau in neuronal somata in $R 406 W^{+/}$, but not in $R 406 W^{-/}$ mice}

Vehicle-treated R406W $\mathrm{W}^{-/-}$mice at 16-18 weeks of age had very low detectable levels of phospho-tau staining using the antibodies AT8 (Figure 1) and AT180 (Figure 2) in the cortex, hippocampus and amygdala. In vehicle-treated $\mathrm{R} 406 \mathrm{~W}^{+/+}$mice of the same age, higher levels of AT8 and AT180 immunoreactivity were observed in the cerebral neuropil (Figures 1 and 2); in the cortex, many pyramidal neurons were stained in their soma and apical dendrites; in the hippocampus and amygdala phospho-tau labeling was more localized in the soma; in the hippocampus, AT8 and AT180 labeling was more intense in the pyramidal layer of CA3 region, with some animals also exhibiting labeling through CA1 region.

Three days of systemic annonacin exposure did not significantly alter the AT8 and AT180 immunoreactivity in any of the investigated brain regions in $\mathrm{R} 406 \mathrm{~W}^{-/-}$mice (Figures 1 and 2). However, $\mathrm{R} 406 \mathrm{~W}^{+/+}$mice treated likewise with annonacin had significantly increased numbers of neurons with somatodentritic immunoreactivity for phospho-tau protein in a dosedependent manner in several brain regions, as compared to vehicle-treated $\mathrm{R} 406 \mathrm{~W}^{+/+}$mice (Figures 1 and 2). Such an increase was observed for pyramidal neurons in the frontal and parietal cortex labeled for both AT8 (Figure 1A-D) and AT180 (Figure 2A-D) epitopes. In the 
hippocampus, there was a significant increase in the intensity of AT8 (Figure 1E-F) and AT180 (Figure 2E-F) labeling in CA2/3 layer neurons.

In the amygdala, neuronal somata were already intensely AT8- and AT180immunoreactive in vehicle-treated $\mathrm{R} 406 \mathrm{~W}^{+/+}$mice and annonacin exposure had no significant additional effect on phospho-tau labeling (not shown). Other brain regions examined in $\mathrm{R} 406 \mathrm{~W}^{+/+}$mice, such as striatum, midbrain and cerebellum had no obvious accumulation of phospho-tau in neurons after annonacin-treatment. In no brain region analyzed, we observed AT8 or AT180 immunoreactivity in glial cells.

Immunohistochemistry with the AT100 and AT270 antibodies gave no signal in vehicle-treated $\mathrm{R} 406 \mathrm{~W}^{-/-}$mice and labeled neuropil (AT270) or nuclei (AT100) in $\mathrm{R} 406 \mathrm{~W}^{+/+}$ mice. However, somatodendritic accumulation of phospho-tau was not detected with the AT100 and AT270 antibodies in vehicle- or annonacin-treated $\mathrm{R} 406 \mathrm{~W}^{-/-}$or $\mathrm{R} 406 \mathrm{~W}^{+/+}$mice (not shown). With the AD2 antibody, very low levels of immunoreactivity were detected in $\mathrm{R} 406 \mathrm{~W}^{+/+}$mice, mainly localized in a few neurons in the deeper layers of the neocortex; no significant alteration was observed upon annonacin treatment (not shown).

\section{Annonacin increases tau protein levels in $\mathrm{R} 406 \mathrm{~W}^{+/+}$, but not in $\mathrm{R} 406 \mathrm{~W}^{/-}$mice}

In order to check whether an increase in tau protein levels contributes to the observed neuronal accumulation of phospho-tau, we performed Western blot analysis in brain tissue extracted from mice treated with 6 or $9 \mathrm{mg} / \mathrm{kg} / \mathrm{d}$ of annonacin or vehicle.

T14 and HT7 antibodies, recognizing specifically human tau, gave no signal in the frontal cortex in $\mathrm{R} 406 \mathrm{~W}^{-/-}$mice (not shown). Expectedly, both antibodies labeled a single band of human tau (the transgene) at $67-69 \mathrm{kD}$ in $\mathrm{R} 406 \mathrm{~W}^{+/+}$mice. This band showed a significant increase upon annonacin treatment (Figure 3A-B).

The Tau5 antibody, which recognizes both mouse and human tau isoforms,

demonstrated that annonacin exposure increased the amount of total tau in $\mathrm{R} 406 \mathrm{~W}^{+/+}$, but not 
in $\mathrm{R}_{406 \mathrm{~W}^{-/}}$mice (Fig. 3C-D). With the Tau5 antibody, two bands were strongly labeled at 67$69 \mathrm{kD}$ and 52-54 $\mathrm{kD}$ in $\mathrm{R} 406 \mathrm{~W}^{+/+}$mice, while only the lower $\mathrm{kD}$ band was intensely labeled in R406W ${ }^{-/-}$mice (Fig. 3D). Therefore, the longer isoform corresponds mainly to human tau, while the shorter isoform corresponds mainly to mouse tau; annonacin exposure increased both long and short isoforms in $\mathrm{R}^{4} 06 \mathrm{~W}^{+/+}$(Figure 3E), but did not increase the short isoform in $\mathrm{R} 406 \mathrm{~W}^{-/-}$mice. As control, we checked $\alpha$-synuclein protein levels, which did not change under annonacin treatment in $\mathrm{R}_{406 \mathrm{~W}^{+/+}}$and $\mathrm{R} 406 \mathrm{~W}^{-/-}$mice (Figure 3D,F).

To determine whether the annonacin-induced increase in total tau was due to augmentation of expression at the transcriptional level, tau mRNA levels were measured by quantitative PCR in cortical tissue from annonacin-intoxicated versus vehicle-exposed animals. The results demonstrated that annonacin does not alter the expression of mouse (Figure 3G) and human tau (Figure 3H). This suggests that the observed increase in tau protein levels is therefore regulated at a posttranscriptional level.

Impairment of tau degradation could contribute to the annonacin-induced accumulation of tau protein by a mechanism involving the inhibition of the ubiquitin-proteasome system, since tau is mainly degraded by this system (David et al., 2002; Goldbaum et al., 2003; Poppek et al., 2006). In order to test this hypothesis, the proteasomal proteolytic activities were measured in cortical tissue from annonacin-intoxicated versus vehicle-exposed animals from both $\mathrm{R} 406 \mathrm{~W}^{+/+}$transgenic and non-transgenic mice lineages. The results showed that annonacin intoxication with $9 \mathrm{mg} / \mathrm{kg} / \mathrm{d}$ inhibits proteasomal chymotrypsin-like (LLVY) and peptidylglutamyl-peptide hydrolase (LLE) activities in $\mathrm{R} 406 \mathrm{~W}^{+/+}$transgenic, but not in nontransgenic mice (Figure 3I).

In summary, annonacin increased both mouse and human transgenic tau protein levels in $\mathrm{R} 406 \mathrm{~W}^{+/+}$, but not in $\mathrm{R} 406 \mathrm{~W}^{-/-}$mice, putatively by reduced proteasomal degradation. 


\section{Annonacin increases the amount of insoluble and phospho-tau in $R 406 W^{+/+}$, but not in}

R406 $W^{-/-}$mice

We checked whether annonacin treatment altered the solubility of tau protein. Western blot analysis demonstrated that treatment with annonacin increased the accumulation of Tau5-, HT7-, AT8-, and AT180-immunoreactive tau protein in the sarcosyl-insoluble fraction of brain homogenates of $\mathrm{R} 406 \mathrm{~W}^{+/+}$mice (Figure $4 \mathrm{~A}$ ), but not of $\mathrm{R} 406 \mathrm{~W}^{-/-}$mice (not shown).

In order to further characterize the effect of annonacin exposure on tau, we compared the amount of phospho-tau in the soluble fraction of homogenates of cortical tissue extracted from $\mathrm{R} 406 \mathrm{~W}^{+/+}$and $\mathrm{R} 406 \mathrm{~W}^{-/-}$mice exposed to annonacin or vehicle. Protein levels of phospho-tau labeled at the AT8 or AT180 epitopes were increased after annonacin exposure in $\mathrm{R}_{406 \mathrm{~W}^{+/+}}$, but not in $\mathrm{R} 406^{-/-}$mice (Figure 4B, C, F). Both long and short tau isoforms labeled with AT8 (Figure 4D) and AT180 (Figure 4G) were increased in R406W ${ }^{+/+}$; the effect was observed with both the lower $(6 \mathrm{mg} / \mathrm{kg})$ and the higher dose $(9 \mathrm{mg} / \mathrm{kg})$ of annonacin exposure, suggesting that annonacin increased the amount of phosphorylated transgenic human tau and of phosphorylated endogenous mouse tau in $\mathrm{R} 406 \mathrm{~W}^{+/+}$transgenic mice, but not in $\mathrm{R} 406 \mathrm{~W}^{-/-}$mice. The ratio between AT8/Tau5 (Figure 4E) and AT180/Tau5 (Figure 4H) increased significantly with annonacin exposure in $\mathrm{R} 406 \mathrm{~W}^{+/+}$mice, suggesting that annonacin increased phosphorylation of tau levels more than just explained by the increase in total tau protein. As control, we assessed the levels of $\beta$-actin in both $\mathrm{R} 406 \mathrm{~W}^{+/+}$and $\mathrm{R} 406 \mathrm{~W}^{-/-}$mice which showed no increase after annonacin exposure (Figure 4B, bottom row).

\section{Annonacin exposure alters the levels of tau kinases}

An increase in phospho-tau could have resulted from an overactivation of tau kinases. Therefore, we tested the hypothesis whether annonacin intoxication alters tau kinases. Candidate tau kinases were selected based on their capacity to phosphorylate tau at both the 
AT8 and AT180 sites (Hanger et al., 2009). Western blot analysis in frontal cortex samples were performed for the kinases SAPK, MAPK (Erk1/2), GSK-3 $\beta$, and Cdk5.

Annonacin intoxication increased the levels of SAPK in both $\mathrm{R} 406 \mathrm{~W}^{+/+}$and $\mathrm{R} 406 \mathrm{~W}^{-/-}$ mice in a dose-dependent manner (Figure 5A, B). The protein levels of MAPK and GSK-3 $\beta$ increased only in $\mathrm{R}_{406 \mathrm{~W}^{+/+}}$mice, but only after $9 \mathrm{~m} / \mathrm{kg}$ annonacin treatment (Figure $5 \mathrm{~A}, \mathrm{C}$, D). Levels of phosphorylated forms of GSK-3 $\beta$ at both activating and inactivating sites were also increased in $\mathrm{R}_{406 \mathrm{~W}^{+/+}}$after annonacin treatment, but only with $6 \mathrm{mg} / \mathrm{kg}$ (Figure 5A, E, F). Protein levels of Cdk5 increased in both $\mathrm{R} 406 \mathrm{~W}^{+/+}$and $\mathrm{R} 406 \mathrm{~W}^{-/-}$in a dose-dependent manner (Figure 5A, G). Activation of Cdk5 requires its association with p35 or p39; a truncated form of $\mathrm{p} 35$, called $\mathrm{p} 25$, is responsible for an overactivation of Cdk5 and has been associated with tau hyperphosphorylation (Cheung and Ip, 2012). We observed a striking increase in the p25/p35 ratio, selectively in $\mathrm{R} 406 \mathrm{~W}^{+/+}$after annonacin exposure, 10 -fold at low and 20-fold at high toxin doses (Figure 5A, H-J).

\section{Annonacin exposure did not cause neuronal death nor microglial reaction}

Histological assessment through quantification of the number of NeuN-immunoreactive neurons demonstrated that a 3-day annonacin intoxication was not sufficient to cause neuronal cell death in $\mathrm{R}_{406 \mathrm{~W}^{+/}}$nor in $\mathrm{R} 406 \mathrm{~W}^{-/-}$mice in the brain regions analysed (Figure 6). Statistical analysis (2-way ANOVA, post hoc-Bonferroni test) demonstrated significant interaction between mice genotype and annonacin treatment for frontal cortex data (Figure 6 A-B; F=3.84; $p=0.046$ ), but not for parietal cortex (Fig. 6 C-D; $F=0.003 ; p=0.996$ ), hippocampus (Figure $6 \mathrm{E}-\mathrm{F} ; \mathrm{F}=0.768 ; \mathrm{p}=0.478$ ), or amygdala (not shown). For all regions, the genotype $\left(\mathrm{R}_{406 \mathrm{~W}^{-/-}}\right.$versus $\left.\mathrm{R} 406 \mathrm{~W}^{+/+}\right)$significantly affected the observed variance, whereas annonacin treatment $(0,6$ or $9 \mathrm{mg} / \mathrm{kg} / \mathrm{d})$ had no significant influence. These results suggest that $\mathrm{R}_{406 \mathrm{~W}^{+/+}}$had significantly lower neuronal number in the cortex (frontal and parietal), hippocampus and amygdala compared to $\mathrm{R} 406 \mathrm{~W}^{-/-}$mice. Such a difference was mostly 
independently of annonacin treatment although there was a tendency of lower neuronal number in $\mathrm{R}_{406 \mathrm{~W}^{+/+}}$treated with $9 \mathrm{mg}$ annonacin compared to $\mathrm{R} 406 \mathrm{~W}$ vehicle-treated $(\mathrm{p}=0.09)$. Annonacin exposure did not cause significant alteration in the number of microglia or astrocytes in the analysed brain regions (cortex and hippocampus) of either $\mathrm{R} 406 \mathrm{~W}^{+/+}$or $\mathrm{R} 406 \mathrm{~W}^{-/-}$mice (Figure 7).

\section{Discussion}

The R406W is an FTDP-17 mutation associated with relatively late onset and long disease duration; although the initial clinical setting resembles $\mathrm{AD}$, frontal lobe symptoms may prevail later in the disease (Ostojic et al., 2004). Transgenic mice carrying the human R406W mutation show an age-dependent somatodentritic accumulation of phosphorylated tau in the neocortex, hippocampus, cerebellum and spinal cord, and NTF-like inclusions were detected at 12 months, but not at 6 months of age (Zhang et al., 2004). The $\mathrm{R} 406 \mathrm{~W}^{+/+}$mice used in our study were 16 to 18 -week old at the time of sacrifice. It seemed an appropriate window to introduce a toxin to assess its effects on the pathological phenotype, because the animals would not have yet developed intense tau pathology or any discernible behavioral deficits at this time point.

Previous work has shown that low nanomolar concentrations of annonacin cause neuronal cell death and induce tau redistribution from the axon to the cell body of striatal neurons in vitro (Escobar-Khondiker et al., 2007). These effects were shown to be associated with annonacin-induced ATP reduction (Escobar-Khondiker et al., 2007). Höllerhage et al. (2009) have extended the findings to additional natural complex I inhibitors, demonstrating their capacity to induce redistribution of phospho-tau to the somatodendritic compartment in good correlation with their capacity to reduce ATP levels. These in vitro models employed fetal neurons, in which tau is physiologically more phosphorylated than in adult neurons 
(Goedert et al. 1994), thus annonacin did only cause a redistribution of phospho-tau, but not a measurable increase in tau phosphorylation (Escobar-Khondiker et al., 2007).

In our present study, we have shown that annonacin exposure increased the number of neurons with somatodentritic accumulation of phospho-tau (AT8 and AT180) in R406W ${ }^{+/}$, but not $\mathrm{R} 406 \mathrm{~W}^{-/-}$mice. This observed effect could have resulted from mere redistribution of phospho-tau from the axonal to the somatodentritic compartment, as in the above mentioned fetal in vitro models (Escobar-Khondiker et al., 2007; Höllerhage et al., 2009), or else there could have been a contribution of an increase in tau protein levels or an increase in tau phosphorylation in the presently used adult in vivo model. In order to investigate these two latter possibilities, we performed Western blot analyses of brain tissue extracts. Annonacin increased the amount of total (both human and mouse) tau protein in $\mathrm{R} 406 \mathrm{~W}^{+/+}$, but not in $\mathrm{R} 406 \mathrm{~W}^{-/-}$mice, without increased mRNA expression. Similarly, in our previous cell culture experiments, annonacin induced an increase in total tau protein levels in absence of increased tau mRNA levels (Escobar-Khondiker et al., 2007). Since annonacin reduced proteasomal proteolytic activity in our present in vivo experiments, and since tau can be degraded by the proteasome (David et al., 2002; Goldbaum et al., 2003), we suggest that annonacin increases total tau level, apparently by reducing proteasomal degradation, but not by increasing tau expression.

Proteasome inhibition and tau protein increase after annonacin exposure was surprisingly only occurring in $\mathrm{R} 406 \mathrm{~W}^{+/+}$, but not in $\mathrm{R} 406 \mathrm{~W}^{-/-}$mice. The excess of proteolytic demand by overexpression a mutated human tau protein in $\mathrm{R} 406 \mathrm{~W}^{+/+}$transgenic mice may already challenge the ubiquitin-proteasome system (UPS) to its limits. There is also evidence that hyperphosphorylation of tau impairs its degradation by the proteasome (Poppek et al., 2006) and the addition of oxidative stress induced by complex I inhibition imposes an additional challenge to the UPS, as shown previously (Höglinger et al., 2005). The combination of these factors may overwhelm the clearance capacity of the UPS, leading to tau 
accumulation. Consistently, we observed no accumulation of the $\alpha$-synuclein protein, which is predominantly degraded by autophagy rather than the UPS in neuronal cells (Vogiatzi et al., 2008).

There is evidence that the R406W mutation is less phosphorylated than the WT tau, especially at the Ser396 and Ser404 phosphorylation sites, which are in close proximity to the mutation (Perez et al., 2000; Miyasaka et al., 2001; Zhang et 2004). Consistently, we have detected very low levels of AD2 immunoreactivity in $\mathrm{R} 406 \mathrm{~W}^{+/+}$mice, and no significant alteration upon annonacin treatment. On the other hand, we have observed that hyperphosphorylation of tau at the AT8 and AT180 sites was increased after annonacin exposure in $\mathrm{R} 406 \mathrm{~W}^{+/+}$mice, and that this increase was not explained by a mere augment in tau protein levels, since the increase in phospho-tau significantly exceeded the increase in total tau. Thus, increased phosphorylation by activation of kinases is likely occurring upon annonacin treatment. We therefore asked which kinases were possibly implicated. We studied candidate kinases known to phosphorylate tau at the AT8 and AT180 site (Hanger et al., 2009). The protein levels of SAPK and Erk1/2 were increased by annonacin treatment in both $\mathrm{R} 406 \mathrm{~W}^{+/+}$ and $\mathrm{R} 406 \mathrm{~W}^{-/-}$mice, and thus unlikely account for the observed tau phosphorylation, which

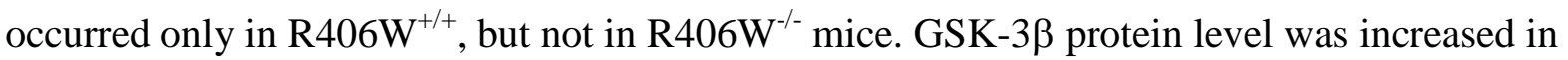
$\mathrm{R}_{406 \mathrm{~W}^{+/+}}$, but not in $\mathrm{R} 406 \mathrm{~W}^{-/-}$mice, at the high annonacin dose. This result correlates with the AT180/Tau5 ratio, which was also increased at the high annonacin dose, suggesting that GSK$3 \beta$ might be implicated in tau phosphorylation at the AT180-reactive T231 epitope. The effect

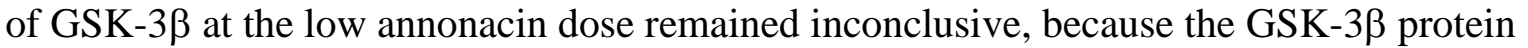
level remained unaltered, and phosphorylation of GSK-3 $\beta$ was increased at both activating and inactivating sites. The Cdk5 protein level was increased in both $\mathrm{R} 406 \mathrm{~W}^{+/+}$and $\mathrm{R} 406 \mathrm{~W}^{-/-}$mice at both annonacin concentrations. The ratio p25/p35 (Cdk5 activator/inhibitor), however, was only increased in $\mathrm{R} 406 \mathrm{~W}^{+/+}$mice, 10 -fold and 20-fold at the low and high annonacin dose, 
respectively. This result correlates with AT8/Tau5 ratio suggesting that Cdk5 might be implicated in tau phosphorylation at the AT8-reactive S202/T205 epitope.

Therefore, GSK-3 $\beta$ and Cdk5 are likely candidates for the observed annonacin effects in $\mathrm{R}_{406 \mathrm{~W}^{+/+}}$mice. These two kinases are proline-directed serine/threonine kinases and are considered to be the major enzymes involved in tau phosphorylation at disease-related sites, especially in abnormal tau hyperphosphorylation in AD (Plattner et al., 2006; Sengupta et al., 2006). Many studies have revealed intriguing functional associations between GSK-3 $\beta$ and Cdk5. The AT180 site T231, which was highly phosphorylated in our annonacin experiments, is phosphorylated by GSK-3 $\beta$, but the phosphorylation was shown to be more intense when tau is pre-phosphorylated by Cdk5 at S235 (Sengupta et al., 1997; Cohen et al., 2004). Prephosphorylation of tau by $\mathrm{Cdk} 5$ stimulates both the rate and the extent of a subsequent phosphorylation catalyzed by GSK-3 (Sengupta et al., 1997). In our R406W ${ }^{+/+}$mice, the Cdk5 activating ratio $\mathrm{p} 25 / \mathrm{p} 35$ was significantly increased at low annonacin doses, whereas both Cdk5 and GSK-3 $\beta$ were activated after high annonacin doses, and consistently there was a significant increase in AT180 labeling.

On the other hand, Cdk5 has also been implicated in a regulatory role onto GSK$3 \beta$ activation (Plattner et al., 2006; Cheung and Ip, 2012). It has been shown in some studies in vivo and in vitro that over-activation of Cdk5 leads to inhibition of GSK-3 $\beta$, or the reverse, that the decreased activity of Cdk5 parallels the enhancement of GSK-3 $\beta$ activity (Hallows et al., 2003; Vandebroek et al., 2005; Plattner et al., 2006). It has been argued that hyperphosphorylation of sites such as AT8 and PHF-1 is not due to a direct action of Cdk5, but is rather a consequence of loss of inhibitory control of GSK3- $\beta$ by Cdk5; such loss was observed in aged mice and associated with increased levels of p25 (Plattner et al., 2006). In our experiments the $\mathrm{p} 25 / \mathrm{p} 35$ ratio paralleled the AT8/Tau5 ratio suggesting that increased Cdk5 levels might be implicated in this tau phosphorylation. Another possibility would be that the 
increased levels of p25 impaired the Cdk5 inhibition over GSK-3 $\beta$, and the latter would then directly hyperphosphorylate tau at AT8 site. Additional studies will be necessary to elucidate the mechanism underlying annonacin effects on tau hyperphosphorylation.

In non-exposed $\mathrm{R} 406 \mathrm{~W}^{+/+}$mice, phospho-tau staining exhibited a homogeneous aspect with no intracellular fibrillar deposits. Annonacin exposure increased the number of neurons with somatodentritic accumulation of phospho-tau, but did not affect the aspect of the staining, which remained homogeneous within the cytoplasm. Although we have detected an increase in the sarcosyl-insoluble fraction of total and phospho-tau in brain homogenates of annonacintreated $\mathrm{R} 406 \mathrm{~W}^{+/+}$mice, we have not observed any structures that morphologically resembled NFT in brain sections. Pathological activity of cytosolic non-fibrillized hyperphosphorylated tau has been reported in several animal models that express human tau suggesting that tau fibrillization or the presence of NFT is not necessary for neurodegeneration (Wittmann et al., 2001; Santacruz et al., 2005). Although we have not observed neuronal cell death, astroglial or microglial reactions, the brief period of annonacin treatment used in our study was enough to accelerate tau changes expected due to the overexpression of the transgene alone. In this regard, annonacin exposure changed the course of the disease and provoked an effect equivalent to an acceleration of the aging process. Consistently, we have also observed tau alterations in other tau-transgenic mice lines, using other complex 1 inhibitors, and also in different exposure protocols (e.g. more chronic and oral administration), but the presentation of these results would be beyond the scope of the present work.

In summary, we have shown that a brief 3-day exposure with annonacin, a natural lipophilic mitochondrial complex I inhibitor, is sufficient to increase tau protein levels, to alter tau kinases, to increase tau phosphorylation and to increase neuronal somatodendritic accumulation of phospho-tau in transgenic mice overexpressing human R406W-mutant tau, demonstrating that an environmental factor can change the course of the disease determined by a genetic factor. 


\section{Acknowledgements}

This work was supported by the Deutsche Forschungsgemeinschaft (HO2402/6-1, HO2402/8-1), the German Ministry of Education and Research (BMBF GEF 10-54), the Centre National de la Recherche Scientifique (CNRS), a Marie Curie Incoming International Fellowship (21996 to E.S.Y.) and the German Academic Exchange Service (DAAD to A.C.F.d.A.). We are very grateful to Dr. Virginia M.-Y. Lee for kindly providing the pair breeders of $\mathrm{R} 406 \mathrm{~W}^{+/+}$transgenic mice. The authors declare no competing financial interests.

\section{Disclosure statement}

All authors disclose any actual or potential conflicts of interest that could inappropriately influence (bias) the work submitted. The data submitted in the present paper have not been published or submitted elsewhere. All procedures concerning animal experimentation had former approval from the appropriate ethical committee. All authors have reviewed and approved the contents of the manuscript. 


\section{References}

Albers, D.S., Swerdlow, R.H., Manfredi, G., Gajewski, C., Yang, L., Parker, W.D.Jr., Beal, M.F., 2001. Further evidence for mitochondrial dysfunction in progressive supranuclear palsy. Ex. Neurol. 168, 196-198.

Baba, Y., Tsuboi, Y., Baker M.C., Uitti, R.J., Hutton, M.L., Dickson, D.W., Farrer, M., Putzke, J.D., Woodruff, B.K., Ghetti, B., Murrell, J.R., Boeve, B.F., Petersen, R.C., Verpillat, P., Brice, A., Delisle, M.B., Rascol, O., Arima, K.D., 2005. The effect of tau genotype on clinical features in FTDP-17. Parkinsonism Relat. Disord. 11, 205-208.

Ballatore, C., Lee, V.M., Trojanowski, J.Q., 2007. Tau-mediated neurodegeneration in Alzheimer's disease and related disorders. Nat. Rev. Neurosci. 8, 663-672.

Bermejo, A., Figadère, B., Zafra-Polo, M.C., Barrachina, I., Estornell, E., Cortes, D., 2005. Acetogenins from Annonaceae: recent progress in isolation, synthesis and mechanisms of action. Nat. Prod. Rep. 22, 269-303.

Bird, T.D., Nochlin, D., Poorkaj, P., Cherrier, M., Kaye, J., Payami, H., Peskind, E., Lampe, T.H., Nemens, E., Boyer, P.J., Schellenberg, G.D., 1999. A clinical pathological comparison of three families with frontotemporal dementia and identical mutations in the tau gene (P301L). Brain $122(\mathrm{Pt} 4), 741-756$

Boeve, B.F., Hutton, M., 2008. Refining frontotemporal dementia with parkinsonism linked to chromosome 17: introducing FTDP-17 (MAPT) and FTDP-17 (PGRN). Arch. Neurol. 65, 460-464.

Caparros-Lefèbvre, D., Elbaz, A., 1999. Possible relation of atypical parkinsonism in the French West Indies with consumption of tropical plants: a case-control study. Caribbean Parkinsonism Study Group. Lancet 354, 281-286.

Champy, P., Guérineau, V., Laprévote, O., 2009. MALDI-TOF MS profiling of Annonaceous acetogenins in Annona muricata products for human consumption. Molecules 14, 52355246. 
Champy, P., Höglinger, G.U., Féger, J., Gleye, C., Hocquemiller, R., Laurens, A., Guérineau, V., Laprévote, O., Medja, F., Lombes, A., Michel, P.P., Lannuzel, A., Hirsch, E.C., Ruberg, M., 2004. Annonacin, a lipophilic inhibitor of mitochondrial complex I, induces nigral and striatal neurodegeneration in rats: possible relevance for atypical parkinsonism in Guadeloupe. J. Neurochem. 88, 63-69.

Champy, P., Melot, A., Guerineau, V., Gleye, C., Fall, D., Höglinger, G.U., Ruberg, M., Lannuzel, A., Laprévote, O., Laurens, A., Hocquemiller, R., 2005. Quantification of acetogenins in Annona muricata linked to atypical parkinsonism in guadeloupe. Mov. Disord. 20, 1629-1633.

Cheung, Z.H., Ip, N.Y., 2012. Cdk5: a multifaceted kinase in neurodegenerative diseases. Trends Cell. Biol. 22, 169-175.

Cohen, P., Goedert, M., 2004. GSK3 inhibitors: development and therapeutic potential. Nat. Rev. Drug Discov. 3, 479-487.

Delobel, P., Lavenir, I., Fraser, G., Ingram, E., Holzer, M., Ghetti, B., Spillantini, M.G., Crowther, R.A., Goedert, M., 2008. Analysis of tau phosphorylation and truncation in a mouse model of tauopathy. Am J Pathol. 172 (Pt. 1), 123-31.

Derbré, S., Roué, G., Poupon, E., Susin, S.-A., Hocquemiller, R., 2005. Annonaceous acetogenins: the hydroxyl groups and THF rings are crucial structural elements for targeting the mitochondria, demonstration with the synthesis of fluorescent squamocin analogues. ChemBioChem. 6, 979-982.

David, D.C., Layfield, R., Serpell, L., Narain, Y., Goedert, M., Spillantini, M.G., 2002. Proteasomal degradation of tau protein. J. Neurochem. 83, 176-85.

Escobar-Khondiker, M., Hollerhage, M., Muriel, M.P., Champy, P., Bach, A., Depienne, C., Respondek, G., Yamada, E.S., Lannuzel, A., Yagi, T., Hirsch, E.C., Oertel, W.H., Jacob, R., Michel, P.P., Ruberg, M., Höglinger, G.U., 2007. Annonacin, a natural mitochondrial complex I inhibitor, causes tau pathology in cultured neurons. J. Neurosci. 27, 7827-7837. 
Foster, N.L., Wilhelmsen, K., Sima, A.A., Jones, M.Z., D'Amato, C.J., Gilman, S., 1997. Frontotemporal dementia and parkinsonism linked to chromosome 17: a consensus conference. Conference Participants. Ann. Neurol. 41, 706-715.

Goedert, M., Jakes, R., Crowther, R.A., Cohen, P., Vanmechelen, E., Vandermeeren, M., Cras, P., 1994. Epitope mapping of monoclonal antibodies to the paired helical filaments of Alzheimer's disease: identification of phosphorylation sites in tau protein. Biochem. J. 301 (Pt 3), 871-877.

Goldbaum, O., Oppermann, M., Handschuh, M., Dabir, D., Zhang, B., Forman, M.S., Trojanowski, J.Q, Lee, V.M., Richter-Landsberg, C., 2003. Proteasome inhibition stabilizes tau inclusions in oligodendroglial cells that occur after treatment with okadaic acid. J. Neurosci. 23, 8872-80.

Hallows, J.L., Chen, K., DePinho, R.A., Vincent, I., 2003. Decreased cyclin-dependent kinase $5(\mathrm{Cdk} 5)$ activity is accompanied by redistribution of Cdk5 and cytoskeletal proteins and increased cytoskeletal protein phosphorylation in p35 null mice. J. Neurosci. 23, 1063310644.

Hanger, D.P., Anderton, B.H., Noble, W., 2009. Tau phosphorylation: the therapeutic challenge for neurodegenerative disease. Trends Mol. Med. 15, 112-9

Höglinger, G.U., Carrard, G., Michel, P.P., Medja, F., Lombes, A., Ruberg, M., Friguet, B., Hirsch, E.C., 2003. Dysfunction of mitochondrial complex I and the proteasome: interactions between two biochemical deficits in a cellular model of Parkinson's disease. J. Neurochem. 86, 1297-1307.

Höglinger, G.U., Lannuzel, A., Khondiker, M.E., Michel, P.P., Duyckaerts, C., Féger, J., Champy, P., Prigent, A., Medja, F., Lombes, A., Oertel, W.H., Ruberg, M., Hirsch, E.C., 2005. The mitochondrial complex I inhibitor rotenone triggers a cerebral tauopathy. J. Neurochem. 95, 930-939. 
Höllerhage, M., Matusch, A., Champy, P., Lombes, A., Ruberg, M., Oertel, W.H., Höglinger, G.U., 2009. Natural lipophilic inhibitors of mitochondrial complex I are candidate toxins for sporadic neurodegenerative tau pathologies. Exp. Neurol. 220, 133-142.

Hutton, M., Lendon, C.L., Rizzu, P., Baker, M., Froelich, S., Houlden, H., Pickering-Brown, S., Chakraverty, S., Isaacs, A., Grover, A., Hackett, J., Adamson, J., Lincoln, S., Dickson, D., Davies, P., Petersen, R.C., Stevens, M., de Graaff, E., Wauters, E., van Baren, J., Hillebrand, M., Joosse, M., Kwon, J.M., Nowotny, P., Che, L.K., Norton, J., Morris, J.C., Reed, L.A., Trojanowski, J., Basun, H., Lannfelt, L., Neystat, M., Fahn, S., Dark, F., Tannenberg, T., Dodd, P.R., Hayward, N., Kwok, J.B., Schofield, P.R., Andreadis, A., Snowden, J., Craufurd, D., Neary, D., Owen, F., Oostra, B.A., Hardy, J., Goate, A., van Swieten, J., Mann, D., Lynch, T., Heutink, P., 1998. Association of missense and 5'-splicesite mutations in tau with the inherited dementia FTDP-17. Nature 393, 702-705.

Ikeuchi, T., Kaneko, H., Miyashita, A., Nozaki, H., Kasuga, K., Tsukie, T., Tsuchiya, M., Imamura, T., Ishizu, H., Aoki, K., Ishikawa, A., Onodera, O., Kuwano, R., Nishizawa, M., 2008. The role of PSEN1 and MAPT R406W mutations. Dement. Geriatr. Cogn. Disord. 26, 43-49.

Kojima, N., Morioka, T., Urabe, D., Yano, M., Suga, Y., Maezaki, N., Ohashi-Kobayashi, A., Fujimoto, Y., Maeda, M., Yamori, T., Yoshimitsu,T., Tanaka, T., 2010. Convergent synthesis of fluorescence-labeled probes of Annonaceous acetogenins and visualization of their cell distribution. Bioorg. Med. Chem. 18, 8630-8641.

Lannuzel, A., Höglinger, G.U., Verhaeghe, S., Gire, L., Belson, S., Escobar-Khondiker, M., Poullain, P., Oertel, W.H,, Hirsch, E.C., Dubois, B., Ruberg, M., 2007. Atypical parkinsonism in Guadeloupe: a common risk factor for two closely related phenotypes? Brain 130, 816-827.

Lannuzel, A., Michel, P.P., Höglinger, G.U., Champy, P., Jousset, A., Medja, F., Lombes, A., Darios, F., Gleye, C., Laurens, A., Hocquemiller, R., Hirsch, E.C., Ruberg, M., 2003. The 
mitochondrial complex I inhibitor annonacin is toxic to mesencephalic dopaminergic neurons by impairment of energy metabolism. Neuroscience 121, 287-296.

Lee, V.M., Goedert, M., Trojanowski, J.Q., 2001. Neurodegenerative tauopathies. Annu. Rev. Neurosci. 24, 1121-1159.

Lindquist, S.G., Holm, I.E., Schwartz, M., Law, I., Stokholm, J., Batbayli, M., Waldemar, G., Nielsen, J.E., 2008. Alzheimer disease-like clinical phenotype in a family with FTDP-17 caused by a MAPT R406W mutation. Eur. J. Neurol. 15, 377-385.

Lindquist, S.G., Schwartz, M., Batbayli, M., Waldemar, G., Nielsen, J.E., 2009. Genetic testing in familial AD and FTD: mutation and phenotype spectrum in a Danish cohort. Clin. Genet. 76, 205-209.

Martinelli, P., Scaglione, C., Lodi, R., Iotti, S., Barbiroli, B., 2000. Deficit of brain and skeletal muscle bioenergetics in progressive supranuclear palsy shown in vivo by phosphorus magnetic resonance spectroscopy. Mov. Disord. 15, 889-893.

Miyasaka T, Morishima-Kawashima M, Ravid R, Heutink P, van Swieten JC, Nagashima K, Ihara Y (2001) Molecular analysis of mutant and wildtype tau deposited in the brain affected by the FTDP-17 R406W mutation. Am J Pathol 158:373-379.

Ostojic, J., Elfgren, C., Passant, U., Nilsson, K., Gustafson, L., Lannfelt, L., Froelich-Fabre, S., 2004. The tau R406W mutation causes progressive presenile dementia with bitemporal atrophy. Dement. Geriatr. Cogn. Disord. 17, 298-301.

Passant, U., Ostojic, J., Froelich-Fabre, S., Gustafson, L., Lannfelt, L., Larsson, E.M., Nilsson, K., Rosen, I., Elfgren, C., 2004. Familial presenile dementia with bitemporal atrophy. Dement. Geriatr. Cogn. Disord. 17, 287-292.

Paxinos, G., Franklin, K.B., 2004. The Mouse Brain in Stereotaxic Coordinates. San Diego, CA: Elsevier.

Perez M, Lim F, Arrasate M, Avila J (2000) The FTDP-17-linked mutation R406W abolishes the interaction of phosphorylated tau with microtubules. J Neurochem 74:2583-2589. 
Plattner, F., Angelo, M., Giese, K.P., 2006. The roles of cyclin-dependent kinase 5 and glycogen synthase kinase 3 in tau hyperphosphorylation. J. Biol. Chem. 281, 25457-25465. Poppek, D., Keck, S., Ermak, G., Jung, T., Stolzing, A., Ullrich, O., Davies, K.J., Grune, T., 2006. Phosphorylation inhibits turnover of the tau protein by the proteasome: influence of RCAN1 and oxidative stress. Biochem. J., 400, 511-520.

Rademakers, R., Dermaut, B., Peeters, K., Cruts, M., Heutink, P., Goate, A., Van Broeckhoven, C., 2003. Tau (MAPT) mutation Arg406Trp presenting clinically with Alzheimer disease does not share a common founder in Western Europe. Hum. Mutat. 22, $409-411$.

Reed, L,A,, Grabowski, T.J., Schmidt, M.L., Morris, J.C., Goate, A., Solodkin, A., Van Hoesen, G.W., Schelper, R.L., Talbot, C.J., Wragg, M.A., Trojanowski, J.Q., 1997. Ann. Neurol. 42, 564-572.

Reed, L.A., Wszolek, Z.K., Hutton, M., 2001. Phenotypic correlations in FTDP-17. Neurobiol. Aging 22, 89-107.

Rizzu, P., Van Swieten, J.C., Joosse, M., Hasegawa, M., Stevens, M., Tibben, A., Niermeijer, M.F., Hillebrand, M., Ravid, R., Oostra, B.A., Goedert, M., van Duijn, C.M., Heutink, P., 1999. High prevalence of mutations in the microtubule-associated protein tau in a population study of frontotemporal dementia in the Netherlands. Am. J. Hum. Genet. 64, 414-421.

Santacruz, K., Lewis, J., Spires, T., Paulson, J., Kotilinek, L., Ingelsson, M., Guimaraes, A., DeTure, M., Ramsden, M., McGowan, E., Forster, C., Yue, M., Orne, J., Janus, C., Mariash, A., Kuskowski, M., Hyman, B., Hutton, M., Ashe, K.H., 2005. Tau suppression in a neurodegenerative mouse model improves memory function. Science. 309, 476-481.

Sengupta, A., Novak, M., Grundke-Iqbal, I., Iqbal, K., 2006. Regulation of phosphorylation of tau by cyclin-dependent kinase 5 and glycogen synthase kinase-3 at substrate level. FEBS Lett. 580, 5925-5933. 
Sengupta, A., Wu, Q., Grundke-Iqbal, I., Iqbal, K., Singh, T.J., 1997. Potentiation of GSK-3catalyzed Alzheimer-like phosphorylation of human tau by Cdk5. Mol. Cell. Biochem. 167, 99-105.

Stamelou, M., Pilatus, U., Reuss, A., Magerkurth, J., Eggert, K.M., Knake, S., Ruberg, M., Schade-Brittinger, C., Oertel, W.H., Höglinger G.U., 2009. J. Cereb. Blood Flow Metab. $29,861-870$

Swerdlow, R.H., Golbe, L.I., Parks, J.K., Cassarino, D.S., Binder, D.R., Grawey, A.E., Litvan, I., Bennett, J.P.Jr., Wooten, G.F., Parker, W.D., 2000. Mitochondrial dysfunction in cybrid lines expressing mitochondrial genes from patients with progressive supranuclear palsy. J. Neurochem. 75, 1681-1684.

van Swieten, J.C., Stevens, M., Rosso, S.M., Rizzu, P., Joosse, M., de Koning, I., Kamphorst, W., Ravid, R., Spillantini, M.G., Niermeijer, M.F., Heutink, P., 1999. Phenotypic variation in hereditary frontotemporal dementia with tau mutations. Ann. Neurol. 46, 617-626.

Vandebroek, T., Vanhelmont, T., Terwel, D., Borghgraef, P., Lemaire, K., Snauwaert, J., Wera, S., Van Leuven, F., Winderickx, J., 2005. Identification and isolation of a hyperphosphorylated, conformationally changed intermediate of human protein tau expressed in yeast. Biochemistry 44, 11466-11475.

Vogiatzi, T., Xilouri, M., Vekrellis, K., Stefanis, L., 2008. Wild type alpha-synuclein is degraded by chaperone-mediated autophagy and macroautophagy in neuronal cells. J. Biol. Chem., 283, 23542-23556.

Weingarten, M.D., Lockwood, A.H., Hwo, S.Y., Kirschner, M.W.., 1975. A protein factor essential for microtubule assembly. Proc. Natl. Acad. Sci.. 72, 1858-1862.

Wittmann, C.W., Wszolek, M.F., Shulman, J.M., Salvaterra, P.M., Lewis, J., Hutton, M., Feany, M.B., 2001. Tauopathy in Drosophila: neurodegeneration without neurofibrillary tangles. Science, 293, 711-714. 
Zhang, B., Higuchi, M., Yoshiyama, Y., Ishihara, T., Forman, M.S., Martinez, D., Joyce, S., Trojanowski, J.Q., Lee, V.M., 2004. Retarded axonal transport of R406W mutant tau in transgenic mice with a neurodegenerative tauopathy. J. Neurosci. 24, 4657-4667. 


\section{Figure Legends}

Figure 1. Immunohistochemistry with the AT8 antibody shows somatodendritic accumulation of tau protein phosphorylated at the S202/T205 epitope after annonacin exposure $(0,6$ or 9 $\mathrm{mg} / \mathrm{kg} / \mathrm{d}) . \boldsymbol{A}-\boldsymbol{D}$, A dose-dependent increase is seen in the frontal $(\boldsymbol{A}, \boldsymbol{B})$ and parietal cortex $(\boldsymbol{C}, \boldsymbol{D})$ in $\mathrm{R}_{406 \mathrm{~W}^{+/+}}$, but not $\mathrm{R} 406 \mathrm{~W}^{-/-}$mice. ANOVA followed by post hoc LSD test. $\boldsymbol{A}$ : * p $=0.038$; $* * \mathrm{p}=0.002 . \boldsymbol{C}: * \mathrm{p}=0.048 ; * * \mathrm{p}=0.003$. Scale bar, $100 \mu \mathrm{m} . \boldsymbol{E}, \boldsymbol{F}$, A significant increase in the intensity of AT8 labeling was observed in hippocampal CA2/3 region after $9 \mathrm{mg} / \mathrm{kg} / \mathrm{d}$ annonacin in $\mathrm{R} 406 \mathrm{~W}^{+/+}$mice, but not in $\mathrm{R} 406 \mathrm{~W}^{-/-}$mice. ANOVA followed by post hoc LSD test, $* * * \mathrm{p}<0.001$. Scale bar, $100 \mu \mathrm{m}$.

Figure 2. Immunohistochemistry with the AT180 antibody shows somatodendritic accumulation of tau protein phosphorylated at the T231epitope after annonacin exposure $(0,6$ or $9 \mathrm{mg} / \mathrm{kg} / \mathrm{d}) \cdot \boldsymbol{A}-\boldsymbol{F}$, A dose-dependent increase after annonacin exposure $(0,6$ or $9 \mathrm{mg} / \mathrm{kg} / \mathrm{d})$ is seen exposure in the frontal $(\boldsymbol{A}, \boldsymbol{B})$ and parietal cortex $(\boldsymbol{C}, \boldsymbol{D})$ and in the hippocampal $\mathrm{CA} 2 / 3$ region $(\boldsymbol{E}, \boldsymbol{F})$ in $\mathrm{R} 406 \mathrm{~W}^{+/+}$, but not $\mathrm{R} 406 \mathrm{~W}^{-/}$mice. ANOVA followed by post hoc LSD test. $\boldsymbol{A}$ : $* \mathrm{p}=0.022 ; * * * \mathrm{p}<0.001 . \boldsymbol{C}: * \mathrm{p}=0.014 ; * * \mathrm{p}=0.002 ; \boldsymbol{E}: * \mathrm{p}=0.030, * * * \mathrm{p}<0.001$. Scale bar, 100 $\mu \mathrm{m}$.

Figure 3. Tau protein level is increased in brains of $\mathrm{R} 406 \mathrm{~W}^{+/+}$, but not $\mathrm{R} 406 \mathrm{~W}^{-/-}$mice, after annonacin exposure (0,6 or $9 \mathrm{mg} / \mathrm{kg} / \mathrm{d}) . \boldsymbol{A}, \boldsymbol{B}$, Total human (i.e. transgenic) tau levels, identified by Western blots using the antibodies T14 and HT7, are increased in R406 ${ }^{+/+}$mice after $6 \mathrm{mg} / \mathrm{kg}\left(\mathrm{T} 14,{ }^{*} \mathrm{p}=0.015 ; \mathrm{HT} 7,{ }^{*} \mathrm{p}=0.045\right)$ and $9 \mathrm{mg} / \mathrm{kg}\left(\mathrm{T} 14,{ }^{*} \mathrm{p}=0,002 ; \mathrm{HT} 7,{ }^{*}\right.$ $\mathrm{p}=0.031)$ of annonacin treatment in comparison to vehicle. $\boldsymbol{C}, \boldsymbol{D}$, With the Tau5 antibody, which labels both human and endogenous mouse tau, the effect was also observed in $\mathrm{R} 406 \mathrm{~W}^{+/+}$ (6 mg/kg, p=0.049; $9 \mathrm{mg} / \mathrm{kg}, \mathrm{p}=0.012)$, but not in $\mathrm{R}_{406 \mathrm{~W}^{-/}}$mice. $\boldsymbol{D}, \boldsymbol{E}$, The Tau 5 antibody 
recognized in $\mathrm{R} 406 \mathrm{~W}^{+/+}$mice $(\boldsymbol{D})$ a long isoform $(\sim 69 \mathrm{kDa})$ corresponding to human transgenic R406W-tau, and a short isoform ( $\sim 55 \mathrm{kDa})$ corresponding to endogenous mouse tau ; both isoforms were increased after $6 \mathrm{mg} / \mathrm{kg}$ long, $* \mathrm{p}=0.045$; short, $* \mathrm{p}=0.048$ ) and $9 \mathrm{mg} / \mathrm{kg}$ (long, ${ }^{*} \mathrm{p}=0.018$; short, ${ }^{*} \mathrm{p}=0.012$ ) annonacin treatment in comparison to $0 \mathrm{mg} / \mathrm{kg}$ in $\mathrm{R} 406 \mathrm{~W}^{+/+}$mice $(\boldsymbol{D}, \boldsymbol{E})$; in $\mathrm{R} 406 \mathrm{~W}^{-/-}$mice, the Tau5 antibody only recognized the short isoform, which was unaltered upon annonacin-treatment $(\boldsymbol{D}) . \boldsymbol{D}, \boldsymbol{F}, \alpha$-synuclein protein levels were not altered in $\mathrm{R} 406 \mathrm{~W}^{-/-}$and $\mathrm{R} 406 \mathrm{~W}^{+/+}$mice upon annonacin treatment. $\boldsymbol{A}-\boldsymbol{D}, \boldsymbol{\beta}$-actin protein levels are shown as loading controls. $\boldsymbol{G}, \boldsymbol{H}$, Quantitative PCR showed no significant increase in total (i.e. mouse and human) tau mRNA $(\boldsymbol{G})$ or human tau mRNA $(\boldsymbol{H})$ after $9 \mathrm{mg} / \mathrm{kg}$ annonacin treatment in neither $\mathrm{R} 406 \mathrm{~W}^{+/+}$nor $\mathrm{R} 406 \mathrm{~W}^{-/-}$mice. As expected, $\mathrm{R} 406 \mathrm{~W}^{+/+}$expressed more total tau $(\mathbf{G}: 0 \mathrm{mg} / \mathrm{kg}, * \mathrm{p}=0.003 ; 9 \mathrm{mg} / \mathrm{kg}, * \mathrm{p}=0.003)$ and human tau tau $(\mathbf{H}: 0 \mathrm{mg} / \mathrm{kg}, *$ $\mathrm{p}=0.001 ; 9 \mathrm{mg} / \mathrm{kg}, * \mathrm{p}=0.001)$ than $\mathrm{R} 406 \mathrm{~W}^{-{ }^{-}}$mice. $\boldsymbol{I}$, However, both the chymotrypsin-like (LLVY) and peptidylglutamyl-peptide hydrolase (LLE) proteasomal proteolytic activities were significantly reduced after $9 \mathrm{mg} / \mathrm{kg}$ annonacin exposure in $\mathrm{R} 406 \mathrm{~W}^{+/+}(\mathrm{LLVY}, * \mathrm{p}=0.024$; LLE, $* \mathrm{p}=0.016)$, but not in $\mathrm{R} 406 \mathrm{~W}^{-/-}$mice. $* \mathrm{p}<0.05$, ANOVA followed by post hoc LSD test, annonacin vs. vehicle $(\boldsymbol{A}-\boldsymbol{E}, \boldsymbol{I}) ;{ }^{*} \mathrm{p}<0.05, \mathrm{R} 406 \mathrm{~W}^{+/+}$vs. $\mathrm{R} 406 \mathrm{~W}^{-/-}(\boldsymbol{G}-\boldsymbol{H})$.

Figure 4. Insoluble and phosphorylated tau are increased in brain tissue of $\mathrm{R} 406 \mathrm{~W}^{+/+}$, but not $\mathrm{R}_{406 \mathrm{~W}^{-/-}}$mice, after annonacin exposure $(0,6$ or $9 \mathrm{mg} / \mathrm{kg} / \mathrm{d})$. $\boldsymbol{A}$, Western blot analysis shows increased human tau (HT7), total tau (Tau5), and phospho-tau (AT8 and AT180) in the sarcosyl-insoluble fraction of brain homogenates after $9 \mathrm{mg} / \mathrm{kg}$ annonacin exposure in $\mathrm{R}_{406 \mathrm{~W}^{+/+}}$mice $(\boldsymbol{A})$, but not in R406W-/- mice (not shown). $\boldsymbol{B}-\boldsymbol{D}$, Also in the soluble fraction of $\mathrm{R} 406 \mathrm{~W}^{+/+}$, but not $\mathrm{R} 406 \mathrm{~W}^{-/-}$mice, annonacin caused a dose-dependent increase in AT8labeled phospho-tau $\left(\boldsymbol{B}, \boldsymbol{C}, 6 \mathrm{mg} / \mathrm{kg},{ }^{*} \mathrm{p}=0.004 ; 9 \mathrm{mg} / \mathrm{kg},{ }^{*} \mathrm{p}=0.026\right)$, affecting both the long (human, $6 \mathrm{mg} / \mathrm{kg},{ }^{*} \mathrm{p}=0.007 ; 9 \mathrm{mg} / \mathrm{kg},{ }^{*} \mathrm{p}=0.010$ ) and short (mouse, $6 \mathrm{mg} / \mathrm{kg},{ }^{*} \mathrm{p}=0.002 ; 9$ 
$\mathrm{mg} / \mathrm{kg}, * \mathrm{p}=0.042)$ isoform $(\boldsymbol{B}, \boldsymbol{D}) ; \beta$-actin protein levels are shown as loading controls. $\boldsymbol{E}$, The ratio of AT8-reactive phospho-tau to Tau5-reactive total tau was also significantly increased in $\mathrm{R}_{406 \mathrm{~W}^{+/+}}(6 \mathrm{mg} / \mathrm{kg}, * \mathrm{p}=0.011 ; 9 \mathrm{mg} / \mathrm{kg}, * \mathrm{p}=0.002)$, but not $\mathrm{R} 406 \mathrm{~W}^{-/-}$mice. $\boldsymbol{B}, \boldsymbol{F}-\boldsymbol{H}$, The phospho-tau antibody AT180 yielded similar results. $\boldsymbol{F}: 6 \mathrm{mg} / \mathrm{kg},{ }^{*} \mathrm{p}=0.011 ; 9 \mathrm{mg} / \mathrm{kg},{ }^{*}$ $\mathrm{p}=0.001 ; \boldsymbol{G}$ : long, $6 \mathrm{mg} / \mathrm{kg},{ }^{*} \mathrm{p}=0.003 ; 9 \mathrm{mg} / \mathrm{kg},{ }^{*} \mathrm{p}=0.001 ; \boldsymbol{G}$ : short, $6 \mathrm{mg} / \mathrm{kg},{ }^{*} \mathrm{p}=0.038 ; 9$ $\mathrm{mg} / \mathrm{kg}, * \mathrm{p}=0.002 ; \boldsymbol{H}: 9 \mathrm{mg} / \mathrm{kg}, * \mathrm{p}=0.007 .{ }^{*} \mathrm{p}<0.05$, ANOVA followed by post hoc LSD test, annonacin vs. vehicle.

Figure 5. Protein levels of tau kinases are differentially altered upon annonacin exposure in brain homogenates of $\mathrm{R} 406 \mathrm{~W}^{+/+}$and $\mathrm{R} 406 \mathrm{~W}^{-/-}$mice after annonacin exposure $(0,6$ or 9 $\mathrm{mg} / \mathrm{kg} / \mathrm{d})$. Representative Western blot bands $(\boldsymbol{A})$ and quantifications thereof $(\boldsymbol{B}-\boldsymbol{J})$ are shown. $\boldsymbol{A}, \boldsymbol{B}$, SAPK levels were increased after both annonacin doses in both $\mathrm{R} 406 \mathrm{~W}^{+/+}(6 \mathrm{mg} / \mathrm{kg}$, * $\mathrm{p}=0.036 ; 9 \mathrm{mg} / \mathrm{kg}, * \mathrm{p}=0.034)$ and $\mathrm{R} 406 \mathrm{~W}^{-/-}$mice $(6 \mathrm{mg} / \mathrm{kg}, * \mathrm{p}=0.012 ; 9 \mathrm{mg} / \mathrm{kg}, * \mathrm{p}=0.004)$. $\boldsymbol{A}, \boldsymbol{C}$, Erk1/2 levels were increased only in $\mathrm{R} 406 \mathrm{~W}^{+/+}$mice after $9 \mathrm{mg} / \mathrm{kg}$ annonacin exposure (* $\mathrm{p}=0.021) . \boldsymbol{A}, \boldsymbol{D}-\boldsymbol{F}, \mathrm{GSK}-3 \beta$ total protein levels were increased only in $\mathrm{R} 406 \mathrm{~W}^{+/+}$mice after 9 $\mathrm{mg} / \mathrm{kg}$ annonacin exposure $(* \mathrm{p}=0.046)$. GSK-3 $\beta$ phosphorylated both at Y216 leading to activation $(\boldsymbol{E})$ and at $\mathrm{S} 9$ leading to inactivation $(\boldsymbol{F})$ was increased only in $\mathrm{R} 406 \mathrm{~W}^{+/+}$mice after $6 \mathrm{mg} / \mathrm{kg}$ annonacin treatment $(\boldsymbol{E}:$ phosphoY216, * p=0.046; $\boldsymbol{F}:$ phosphoS9, p=0.003). $\boldsymbol{A}, \boldsymbol{G}$, Cdk5 protein levels were increased after both the low and high annonacin doses in both $\mathrm{R} 406^{+/+}(6 \mathrm{mg} / \mathrm{kg}, * \mathrm{p}=0.046 ; 9 \mathrm{mg} / \mathrm{kg}, * \mathrm{p}=0.005)$ and $\mathrm{R} 406 \mathrm{~W}^{-/-}(6 \mathrm{mg} / \mathrm{kg}, * \mathrm{p}=0.013 ; 9$ $\mathrm{mg} / \mathrm{kg}, * \mathrm{p}=0.021)$ mice. $\boldsymbol{A}, \boldsymbol{H}-\boldsymbol{J}$, In $\mathrm{R} 406 \mathrm{~W}^{+/+}$, but not in $\mathrm{R} 406 \mathrm{~W}^{-/-}$mice, after annonacin exposure, there was a decrease in p35 levels $(\boldsymbol{H}: 6 \mathrm{mg} / \mathrm{kg}, * \mathrm{p}=0.02 ; 9 \mathrm{mg} / \mathrm{kg}$, * p=0.018) along with an increase in p25 levels $(\boldsymbol{I},(6 \mathrm{mg} / \mathrm{kg}, * \mathrm{p}=0.027 ; 9 \mathrm{mg} / \mathrm{kg}, * \mathrm{p}=0.03)$, resulting in an increase in the $\mathrm{p} 25 / \mathrm{p} 35$ ratio $\left(\boldsymbol{J},\left(6 \mathrm{mg} / \mathrm{kg},{ }^{*} \mathrm{p}=0.049 ; 9 \mathrm{mg} / \mathrm{kg},{ }^{*} \mathrm{p}=0.045\right)\right.$, reaching approximately 10 -fold of normal levels at low and 20-fold at high toxin doses. In $\mathrm{R} 406 \mathrm{~W}^{-/-}$ 
mice, $9 \mathrm{mg} / \mathrm{kg}$ annonacin resulted in decrease in both p35 $(\mathrm{H}, * \mathrm{p}=0.004)$ and p25 (I, * $\mathrm{p}=0.027){ }^{*} \mathrm{p}<0.05$, ANOVA followed by post hoc LSD test, annonacin vs. vehicle.

Figure 6. Immunohistochemistry with the NeuN antibody labeling neurons in $\mathrm{R} 406 \mathrm{~W}^{-/-}$and $\mathrm{R}_{406 \mathrm{~W}^{+/+}}$mice treated with annonacin $(0,6$ or $9 \mathrm{mg} / \mathrm{kg} / \mathrm{d}) . \boldsymbol{A}-\boldsymbol{F}$, The number of NeuN ${ }^{+}$ neurons were analyzed in frontal cortex $(\boldsymbol{A}, \boldsymbol{B})$ and parietal cortex $(\boldsymbol{C}, \boldsymbol{D})$, as well as labeling intensity in the granular layer of the hippocampal CA2/3 region $(\boldsymbol{E}, \boldsymbol{F})$. For all these analyses, the $\mathrm{R} 406 \mathrm{~W}^{+/+}$mice had significantly lower numbers compared to R406W ${ }^{-/-}$(2-way ANOVA; frontal cortex $\mathrm{p}=0.000$, parietal cortex $\mathrm{p}=0.001$, hippocampus $\mathrm{p}=0.000$ ), whereas annonacin treatment had no effect. Scale bars: $50 \mu \mathrm{m}$ in $\boldsymbol{B}$ and $\boldsymbol{D} ; 100 \mu \mathrm{m}$ in $\boldsymbol{F}$.

Figure 7. Immunohistochemistry with the IbaI antibody labeling microglia and GFAP antibody labeling astrocytes neurons in $\mathrm{R} 406 \mathrm{~W}^{-/-}$and $\mathrm{R} 406 \mathrm{~W}^{+/+}$mice treated with annonacin (0, 6 or $9 \mathrm{mg} / \mathrm{kg} / \mathrm{d}) . \boldsymbol{A}-\boldsymbol{H}$, The figure shows representative results for microglia in frontal cortex $(\boldsymbol{A}, \boldsymbol{B})$, parietal cortex $(\boldsymbol{C}, \boldsymbol{D})$ and hipocampus $(\boldsymbol{E}, \boldsymbol{F})$ and for astrocytes in the hippocampus $(\boldsymbol{G}, \boldsymbol{H})$. There were no significant differences between the groups. Scale bars: $100 \mu \mathrm{m}$. 

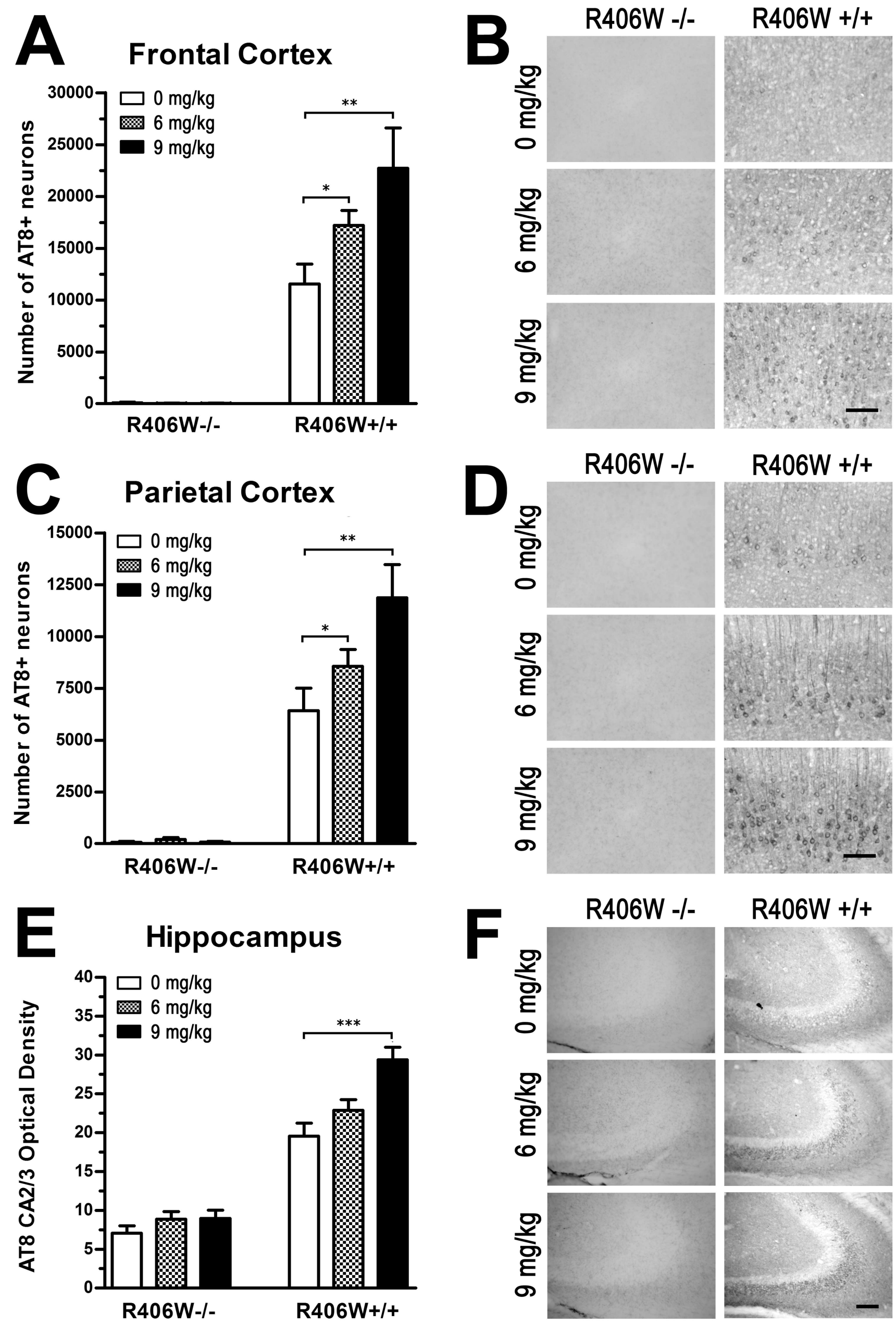

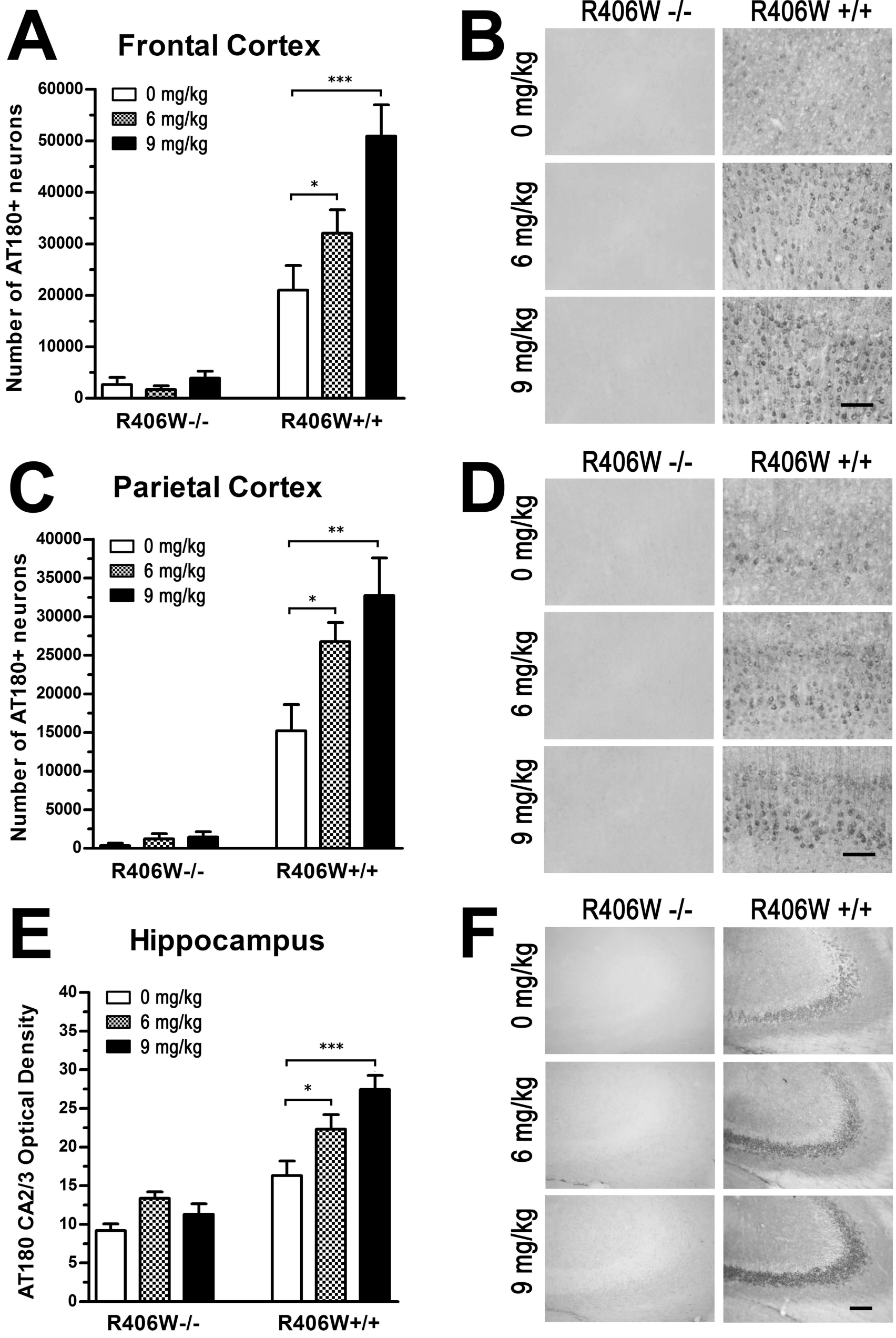
A $\quad \mathrm{R406W}^{+/+} \quad \mathrm{R}^{++} \quad \mathrm{W}^{+/+}$
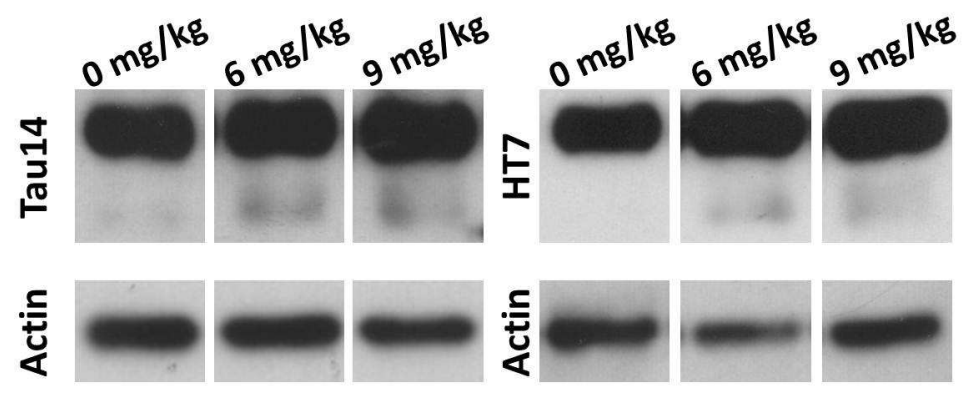

D

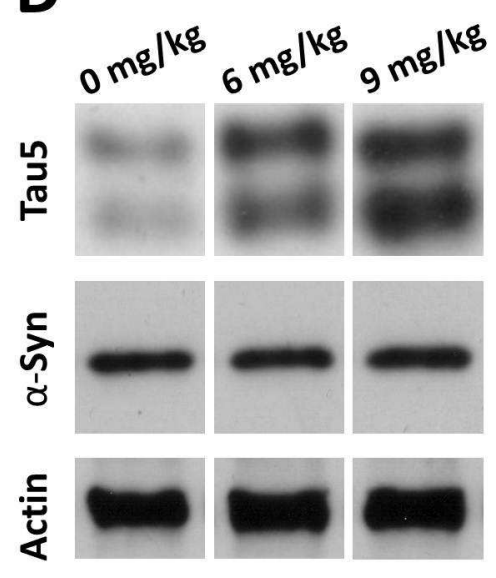

$0 m g^{k B}{ }_{6} m g g^{k B} g m g g^{k B}$
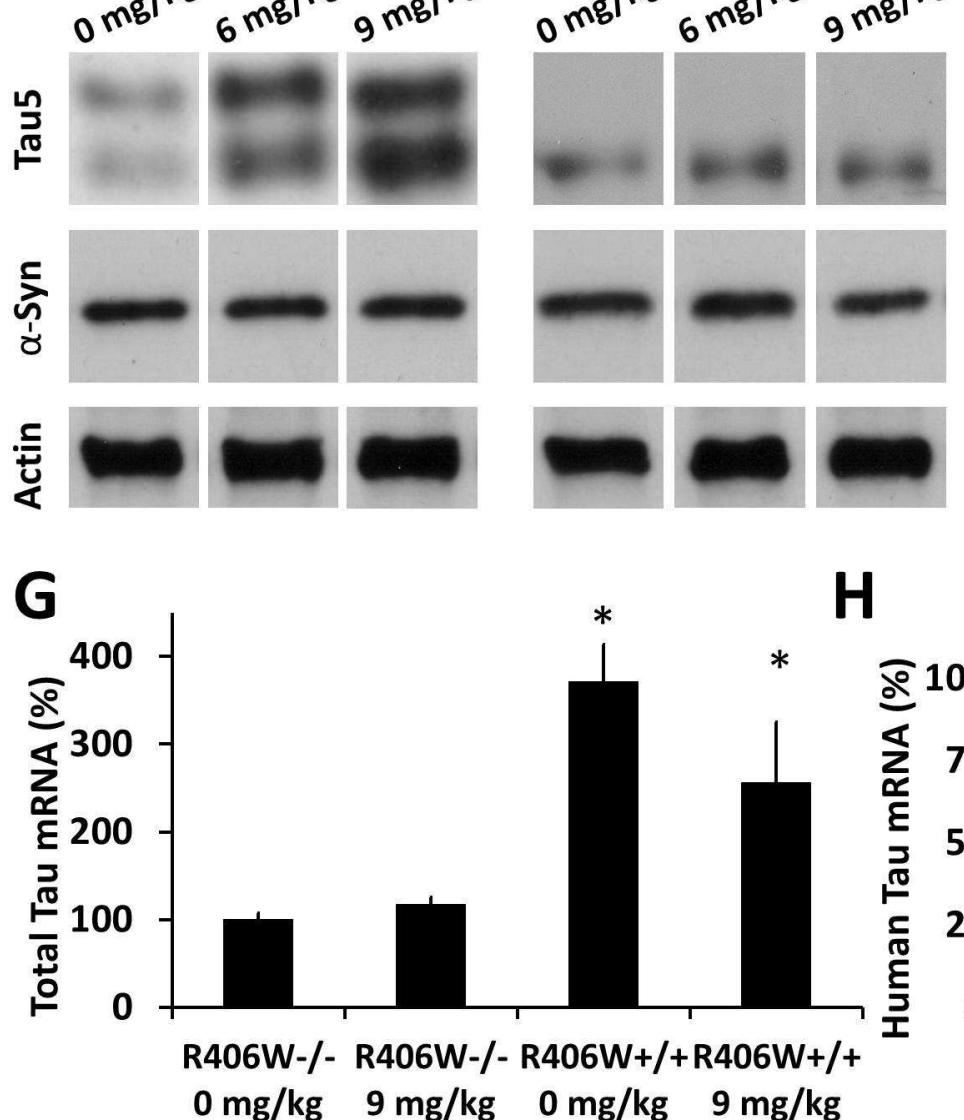

$69 \mathrm{kDa}$

$55 \mathrm{kDa}$

$44 \mathrm{kDa}$

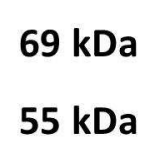

$14 \mathrm{kDa}$

$44 \mathrm{kDa}$

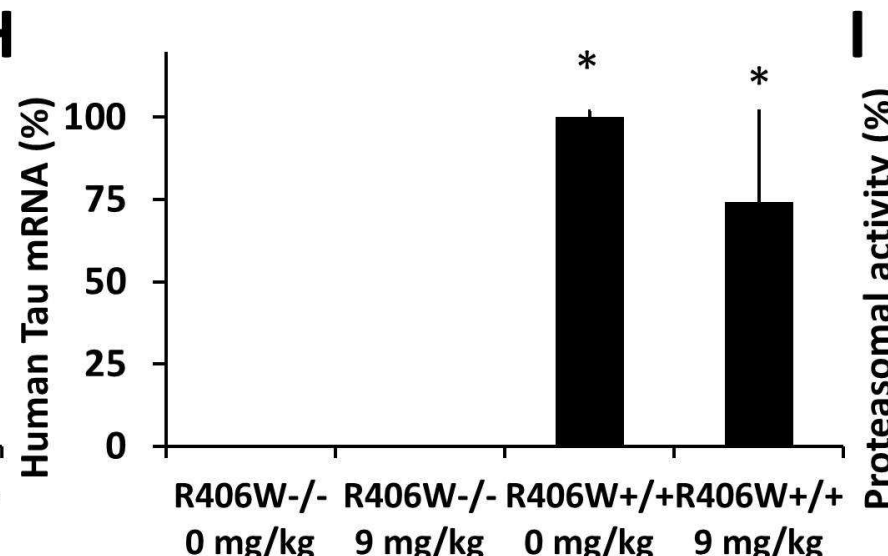

E
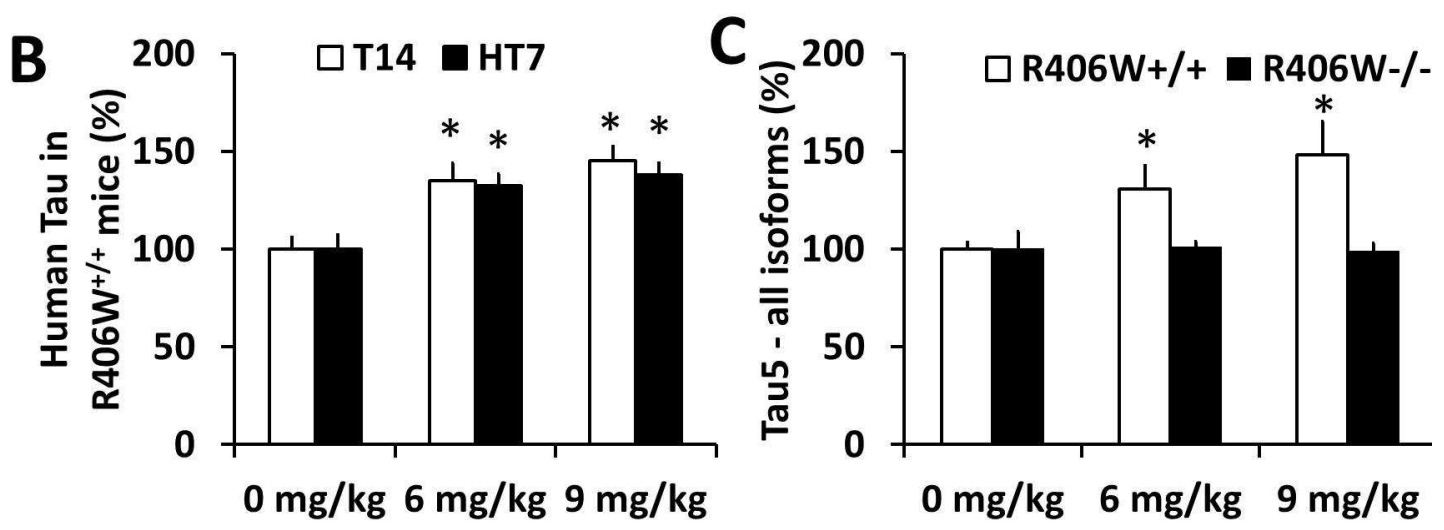

$\mathbf{F}$
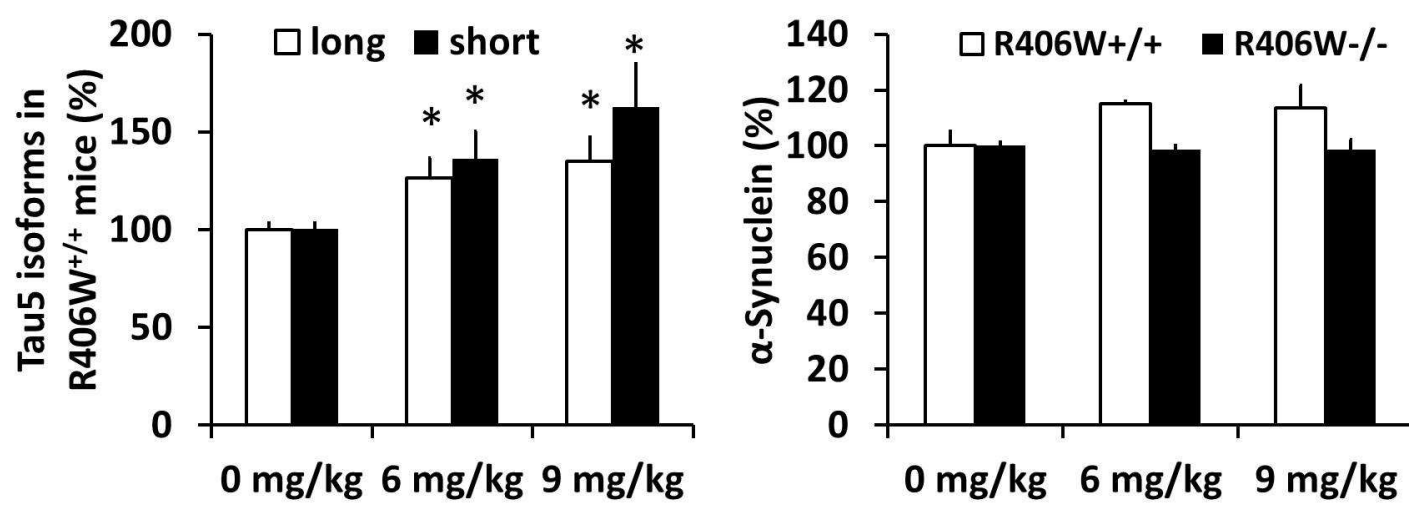

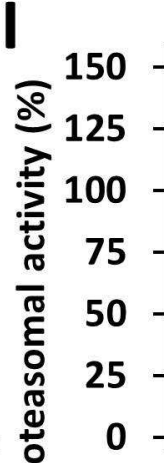
$0 \mathrm{mg} / \mathrm{kg} \quad 9 \mathrm{mg} / \mathrm{kg} \quad 0 \mathrm{mg} / \mathrm{kg} \quad 9 \mathrm{mg} / \mathrm{kg}$

\section{QLLVY $\square$ LLE}

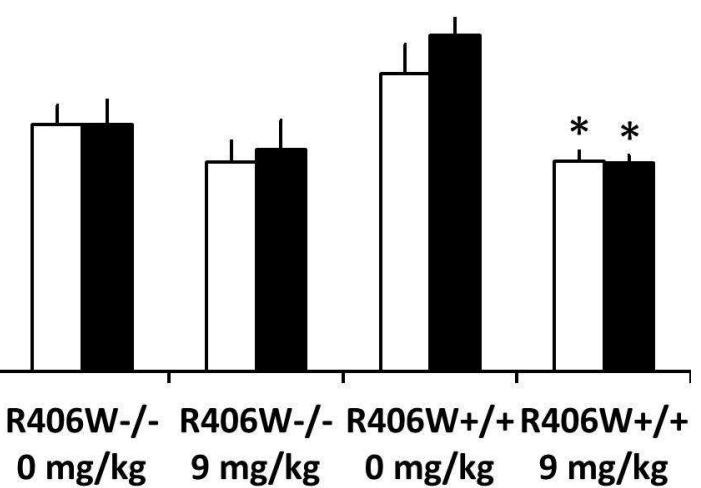


A

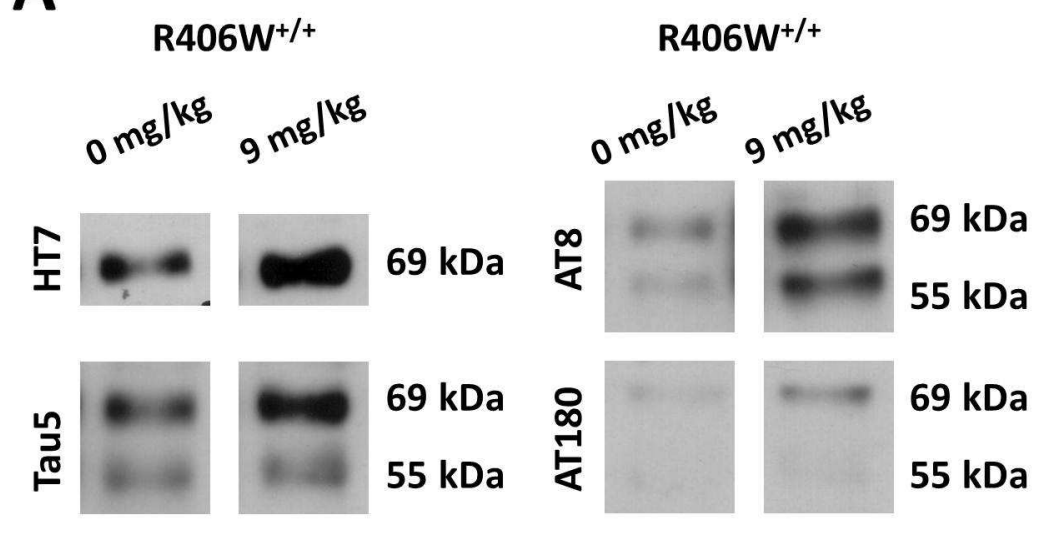

B

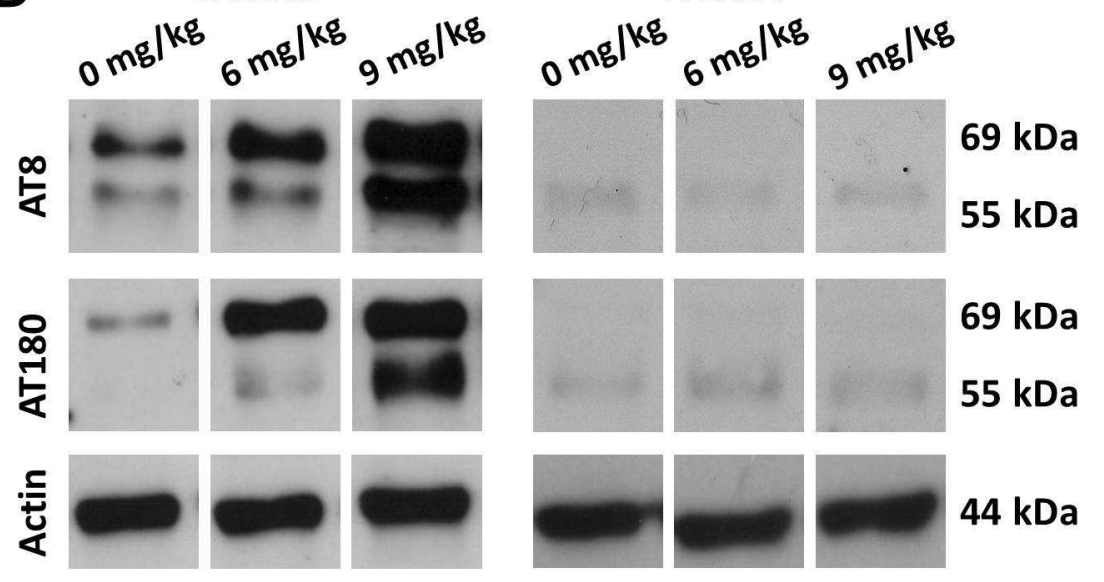

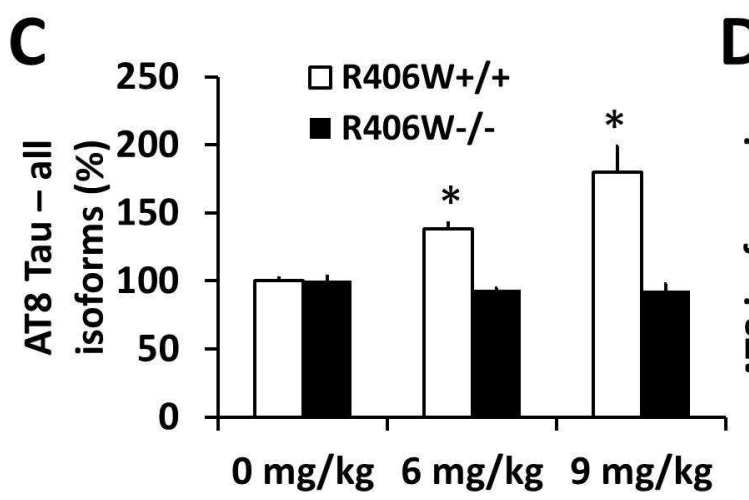

D

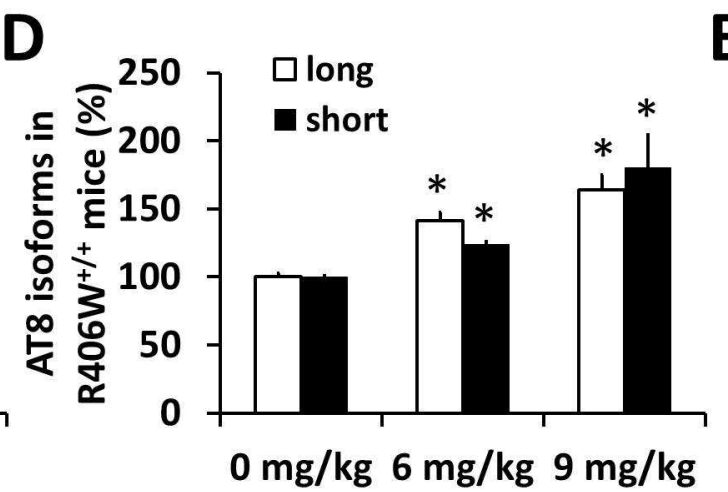

G

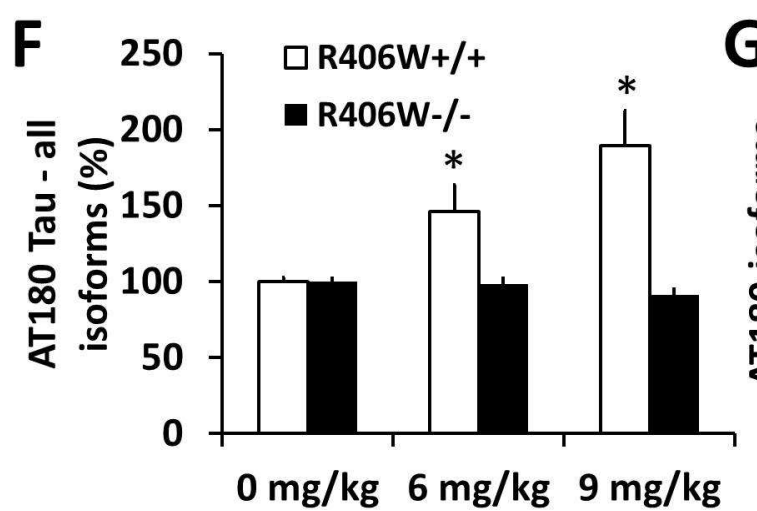

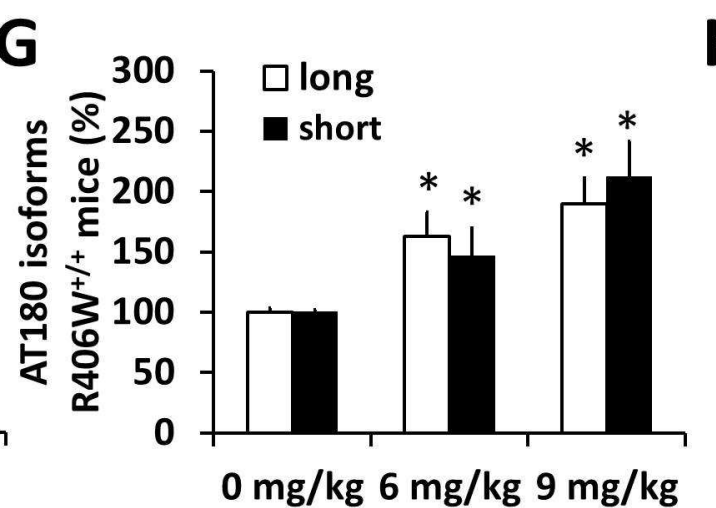

E

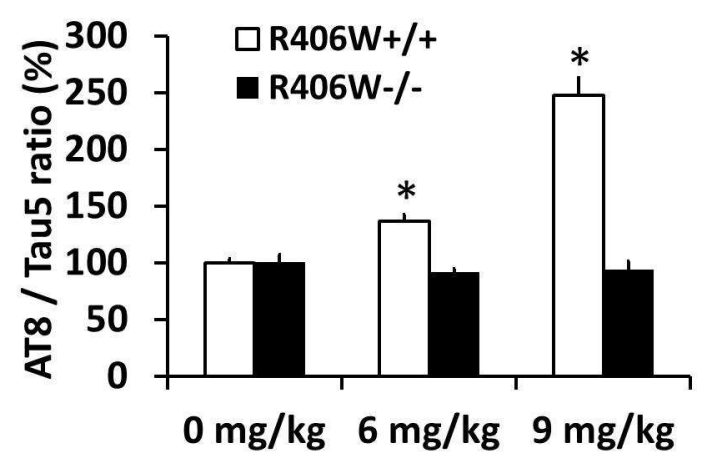

H

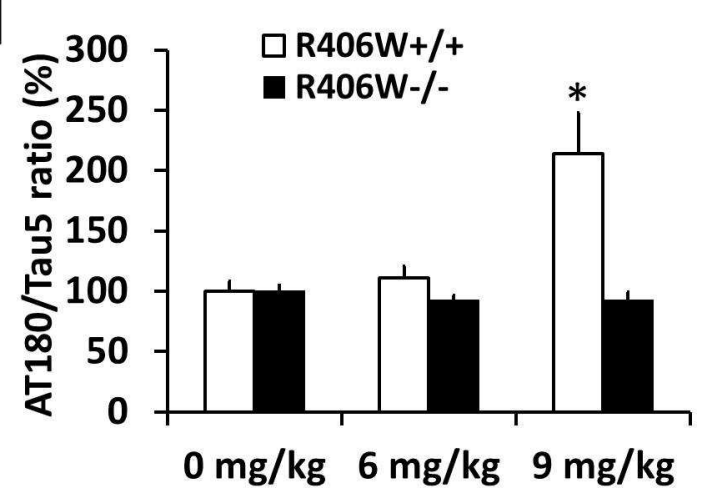



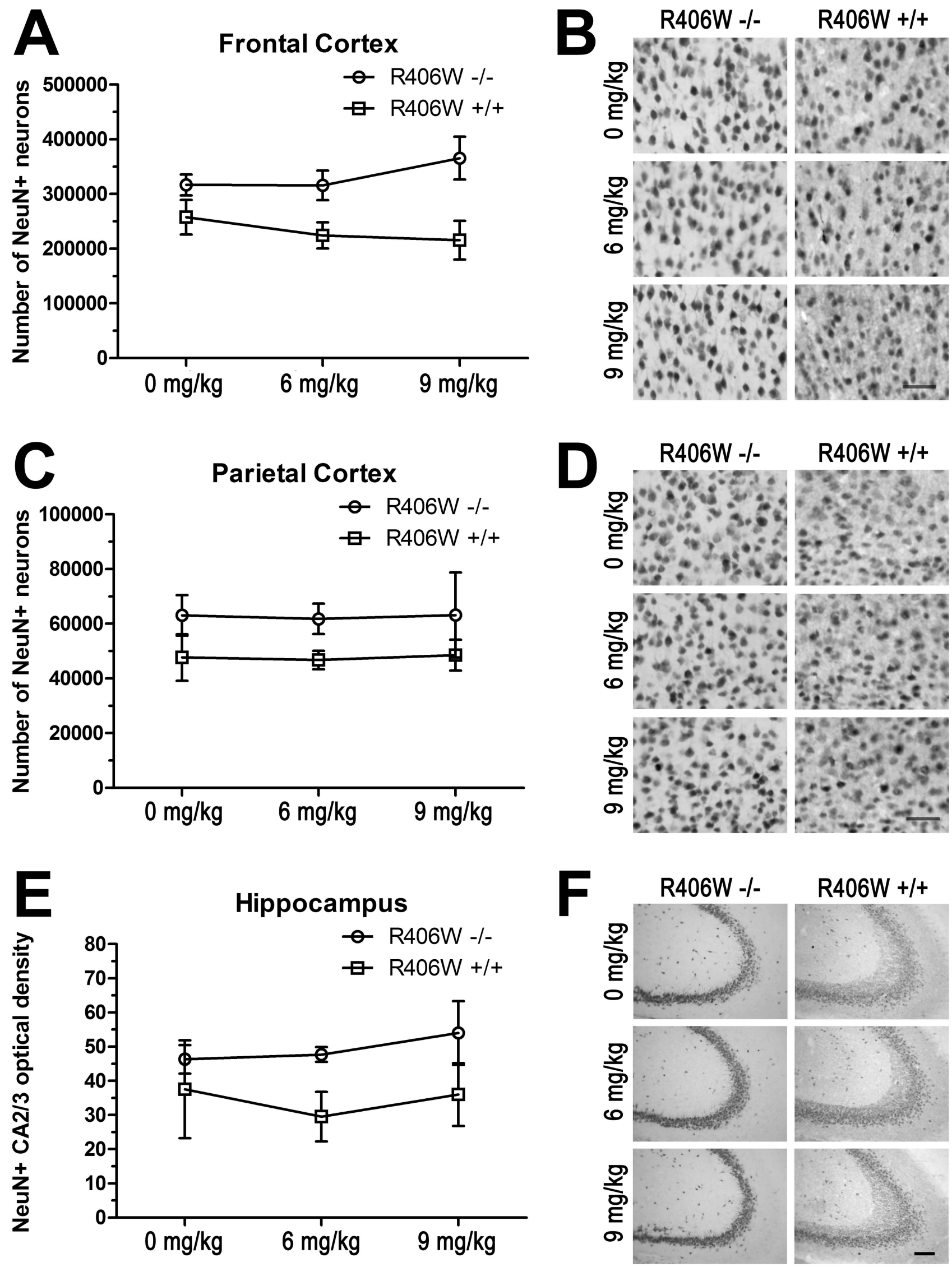

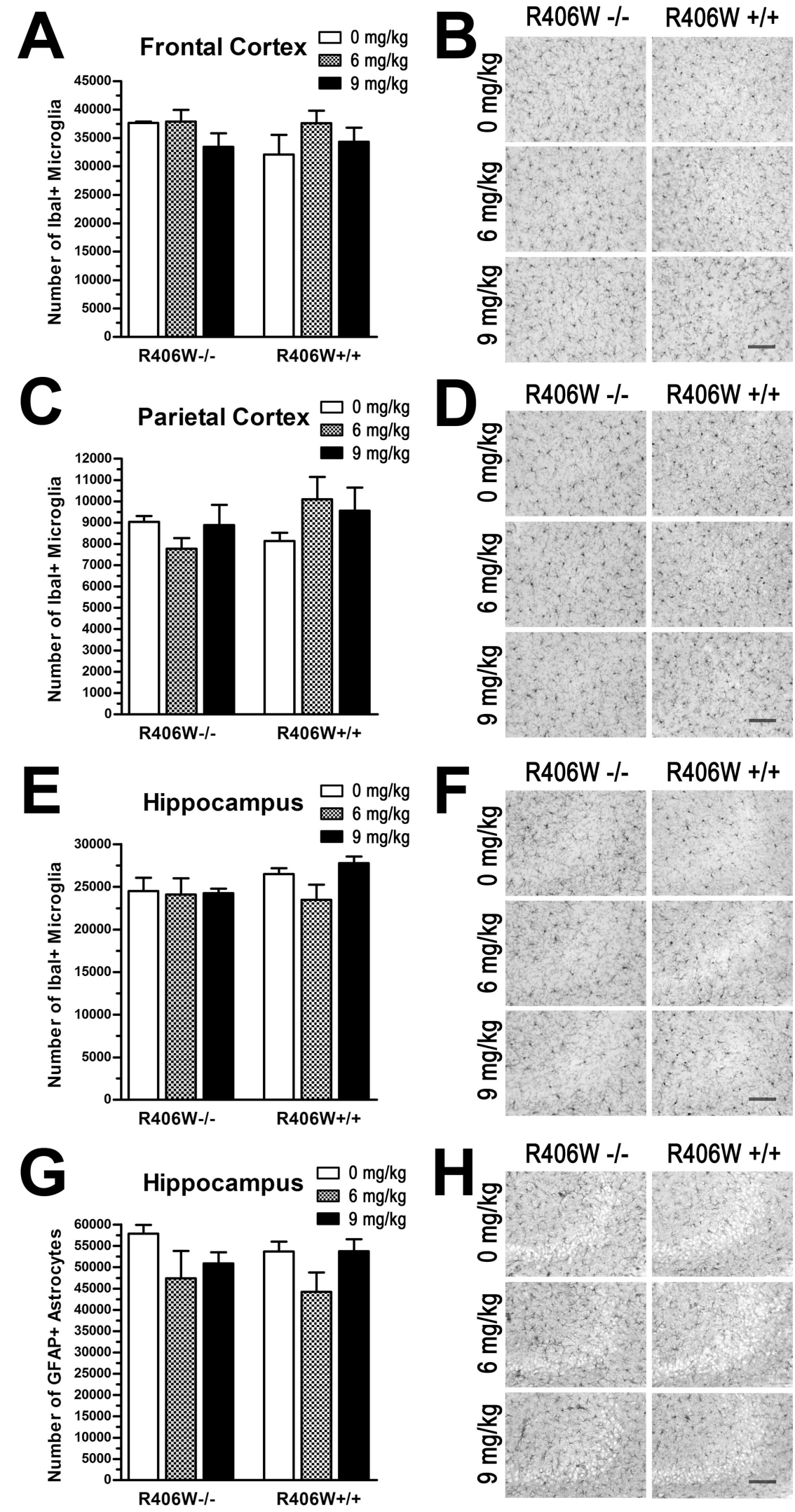